Research Article

\title{
Experimental Study and Reliability Analysis of Flexural Capacity of RC Beams Reinforced with 600 MPa Grade Steel
}

\author{
Xianhua Yao (D), Yulong Zhang (D), Junfeng Guan (iD, Lielie Li $(\mathbb{D}$, Haichao Liu (D), \\ Ruicong Han $(\mathbb{D}$, and Junyi Xi $\mathbb{D}$
}

\begin{abstract}
School of Civil Engineering and Communication, North China University of Water Resources and Electric Power, Zhengzhou 450045, China
\end{abstract}

Correspondence should be addressed to Junfeng Guan; shuaipipi88@126.com

Received 31 August 2020; Revised 11 November 2020; Accepted 23 November 2020; Published 17 December 2020

Academic Editor: Yifeng Ling

Copyright (C) 2020 Xianhua Yao et al. This is an open access article distributed under the Creative Commons Attribution License, which permits unrestricted use, distribution, and reproduction in any medium, provided the original work is properly cited.

Flexural capacity of beams reinforced with 400 or $500 \mathrm{MPa}$ grade steel can be accurately estimated by using equations provided in design codes. Recently, $600 \mathrm{MPa}$ grade steel has evolved in the construction industry, and the applicability of existing equations for this grade of steel should be verified by performing experimental investigation. By conducting tests on concrete beams reinforced with $600 \mathrm{MPa}$ grade high-strength steel, this study investigates the flexural performance for different concrete strength grades and different reinforcement ratios. Flexural capacities of concrete beams reinforced with $400 \mathrm{MPa}, 500 \mathrm{MPa}$, and $600 \mathrm{MPa}$ grade steel are analyzed based on equations in various codes and based on experimental studies in the literature. Furthermore, this study performs reliability analysis and verifies the three design values of $600 \mathrm{MPa}$ grade steel yield strength in relation to the experimental performance and recommends the appropriate design values of $600 \mathrm{MPa}$ grade steel yield strength. Research results show that when the measured values of yield strength of the steel bars and concrete strength are used, the ratio of the measured failure moment value to the calculated value for various beams based on different codes is nearly 1.0, demonstrating the high degree of fitting. Finally, the reliability analysis shows that the design yield strength of the $600 \mathrm{MPa}$ grade high-strength steel bars should be taken as $520 \mathrm{MPa}$.

\section{Introduction}

In recent years, use of high-strength steel bars has improved the performance of concrete structures and reduced the amount of steel bars. High-strength steel bars (with yield strength $>500 \mathrm{MPa}$ ) have evolved as a new type of environmentally friendly building materials [1-4]. In the United States, South Korea, Canada, and Japan, $70 \%$ of the steel reinforcement in reinforced concrete has the strength of $400 \mathrm{MPa}$ and above $25 \%$ has the strength of $500 \mathrm{MPa}$. In Germany, France, and the United Kingdom, the amount of the $500 \mathrm{MPa}$ steel bar has reached $70 \%$ of the total reinforcement, and the construction industry is demanding for the $600 \mathrm{MPa}$ steel bar. Based on the data of steel processing, saving 10 million tons of steel is equivalent to saving 18 million tons of iron ore, saving 6.5 million tons of standard coal, and reducing a large amount of exhaust gas and dust emissions. Therefore, the application of high-strength reinforcement can not only save energy and resources but also reduce emissions. In addition, new materials and environmentally friendly materials have always been the goal pursued by engineers and researchers [5-7]. High-strength steel with yield strength $\left(f_{y}\right)$ greater than $500 \mathrm{MPa}$ has been developed in several markets worldwide [8]. Development of high-strength steel with different grades has been extensively studied all over the world, such as steel grade $600 \mathrm{MPa}$ [9], steel grade $700 \mathrm{MPa}$ [10], steel grade $700 \mathrm{MPa}$ [11], steel grade $780 \mathrm{MPa}$ [12], and steel grade $800 \mathrm{MPa}$ [13]. Hao et al. [14] studied the mechanical properties and microstructure of HRB600 steel bars (600 MPa grade) after subjecting to high temperature. Zhang et al. [15] studied the mechanical properties of steel fiber concrete at high temperatures. Saleem et al. [16] studied the bonding and deformation properties of reinforced concrete (RC) that used steel with 
the yield strength of $690 \mathrm{MPa}$. Harries et al. [17] believed that the application of high-strength steel bars in concrete can achieve significant economic benefits. Barcley and Kowalsky [18] studied the seismic performance of high-strength RC columns, and the results showed that RC columns with steel having the yield strength of $550 \mathrm{MPa}$ behaved similar to columns with steel having yield strength of $420 \mathrm{MPa}$ steel bars in terms of the early stage of yield, length of plastic hinge, and capacity consumption. However, the yield strength of RC columns having $550 \mathrm{MPa}$ grade steel was markedly improved. The characteristic of steel bar fracture appears under low deformation. Zhang et al. [19] found that high-strength concrete columns with HRB600 steel bars possessed good hysteretic behavior, deformability, and energy dissipation capacity as well as seismic resilience. Aldabagh and Alam [20] found that high-strength steel (HSS), i.e., ASTM A1035 grade 690, has been gaining popularity in the last two decades due to its considerably higher strength and corrosion resistance. Baek et al. [21] revealed that the shear friction resistance of grade $600 \mathrm{MPa}$ (87 ksi) reinforcing bars was greater than that of $400 \mathrm{MPa}$ (58 ksi) reinforcing bars. Li et al. [22] found that the combination of concrete with C 80 grade and steel bars with HRB600 grade was a reasonable match for strength.

Definition of high-strength grade differs from specifying institutions. For instance, the International Organization for Standardization Standard ISO6935-2-2015 stipulates the high-strength steel bar grades as B600A-R, B600B-R, and B600C-R, the American standard ASTM A615-18el stipulates the high-strength steel grade as $100 \mathrm{ksi}(690 \mathrm{MPa})$, the Korean standard KSD3504-2011 stipulates the high-strength steel grade as SD600 and SD700, the Singapore standard SS 560-2016 stipulates high-strength steel bar grades as B600A, B600B, and B600C, and the Chinese standard GB/T1499.22018, Part 2 of steel for RC, hot-rolled ribbed steel bar stipulates the high-strength steel bar as HRB600 [23]. However, the formulas for calculating the bearing capacity of RC beams made with high-strength steel bars are not the same in various countries, and even, the formulas used by different industries are sometimes different in the same country. For example, in China, reinforcing steel is produced with different standards, namely, GB 50010 [24], DL/T 5057 [25], SL/T 191 [26], JTJ 267 [27], JTG D62 [28], and TB10002.3 [29]. The applicability of equations developed for $400 \mathrm{MPa}$ and $500 \mathrm{MPa}$ steel bars has been generally deemed applicable for high-strength bars by various countries. However, experimental verification is necessary to determine whether high-strength steel bars based on different standards are suitable to be used as $600 \mathrm{MPa}$ steel bars and whether the bars possess sufficient safety reserves. Determining the properties of materials through experiments is also a common method used by researchers [30-36]. In addition, the grades of steel bars are updated quickly, and the codes often lag behind. The current Chinese code GB 50010 Design Code for Concrete Structures stipulates that the highest yield strength of ordinary stressed steel bars is $500 \mathrm{MPa}$. Therefore, the applicability of high-strength steel bars should be urgently recognized in such codes; otherwise, it will affect its application in engineering.
TABLE 1: Main physical and mechanical properties of cement.

\begin{tabular}{|c|c|c|c|c|c|c|c|c|c|}
\hline \multicolumn{4}{|c|}{$\begin{array}{l}\text { Compressive strength } \\
(\mathrm{MPa})\end{array}$} & \multicolumn{4}{|c|}{$\begin{array}{l}\text { Flexural strength } \\
(\mathrm{MPa})\end{array}$} & \multicolumn{2}{|c|}{ Density $\left(\mathrm{kg} / \mathrm{m}^{3}\right)$} \\
\hline P.O4 & & P.O & 52.5 & P.O & 42.5 & P.O & 52.5 & P.O42.5 & P.O52.5 \\
\hline $\begin{array}{l}3 \mathrm{~d} \\
22.3\end{array}$ & $\begin{array}{l}28 \mathrm{~d} \\
49.4\end{array}$ & $\begin{array}{c}3 \mathrm{~d} \\
26.5\end{array}$ & $\begin{array}{l}28 \mathrm{~d} \\
57.7\end{array}$ & $\begin{array}{l}3 \mathrm{~d} \\
5.2\end{array}$ & $\begin{array}{c}28 \mathrm{~d} \\
9.1\end{array}$ & $\begin{array}{l}3 \mathrm{~d} \\
6.5\end{array}$ & $\begin{array}{c}28 \mathrm{~d} \\
9.8\end{array}$ & 3043 & 3244 \\
\hline
\end{tabular}

Researchers have identified the safe design value of $600 \mathrm{MPa}$ steel bars. However, researchers are not unanimous about the yield strength of the $600 \mathrm{MPa}$ steel bar, and this causes inconvenience in design. Chen et al. [37] and Rong et al. [38] studied the flexural performance of RC beams with $600 \mathrm{MPa}$ grade steel under concentrated load. The research results showed that the bending failure mode was the same as that of ordinary reinforced (HRB500 and HRB400) concrete beams. The flexural bearing capacity could still be calculated according to the equations for the flexural bearing capacity of the normal RC section specified in the current codes. When the design tensile strength of the $600 \mathrm{MPa}$ grade steel bar was set to $500 \mathrm{MPa}$, sufficient safety reserve was maintained. However, Zhang et al. [39] suggested that when the yield strength of $600 \mathrm{MPa}$ grade steel bars was taken as $520 \mathrm{MPa}$, the equation for design of concrete structures (GB 50010) could be safely used for calculating flexural bearing capacity of RC beams with $600 \mathrm{MPa}$ steel bars. In order to study the applicability of codes from various countries in the design of RC beams with high-strength steel bars, this research experimentally investigates the flexural bearing capacity of beams with $600 \mathrm{MPa}$ high-strength reinforcement and different strengths of concrete and combines the test results with those of other scholars to analyze the bearing capacity of RC beams. Finally, the reliability of the three design values (500 MPa, $520 \mathrm{MPa}$, and $545 \mathrm{MPa}$ ) of $600 \mathrm{MPa}$ grade steel yield strength is verified in relation to the experimental results, and the appropriate design value of $600 \mathrm{MPa}$ grade steel yield strength is selected.

\section{Experimental Study for RC Beams with 600 MPa Steel Bars}

2.1. Material. Four concrete grades were used in this experiment, denoted by C30, C40, C50, and C60. Physical and mechanical properties of cement are shown in Table 1 (Chinese standard GB 1752007 [40]). Fine aggregate used in this experiment was river sand with the maximum size of $2.5 \mathrm{~mm}$. Material properties of the river sand are presented in Table 2. Coarse aggregate used in this experiment was crushed aggregate, and its properties are shown in Table 3. A high-range water-reducing admixture was used to achieve good workability. Concrete mixture proportion for the four grades of concrete can be found in Table 4 .

The size, reinforcement arrangement, and material properties of tested beams are listed in Table 5 . In the table, $f_{\text {cu }}$ (average value from three cubes with the dimensions of $150 \mathrm{~mm} \times 150 \mathrm{~mm} \times 150 \mathrm{~mm})$ is the cube compressive strength and $f_{\mathrm{ts}}$ (average value from three cubes with the dimensions of $150 \mathrm{~mm} \times 150 \mathrm{~mm} \times 150 \mathrm{~mm}$ ) is the splitting 
Table 2: Machine-made sand.

\begin{tabular}{lccc}
\hline Apparent density $\left(\mathrm{kg} / \mathrm{m}^{3}\right)$ & Sediment percentage & Bulk density $\left(\mathrm{kg} / \mathrm{m}^{3}\right)$ & Fineness modulus \\
\hline 2700 & 0.5 & 1610 & 2.6 \\
\hline
\end{tabular}

TABle 3: Coarse aggregate.

\begin{tabular}{lccc}
\hline Apparent density $\left(\mathrm{kg} / \mathrm{m}^{3}\right)$ & Sediment percentage & Bulk density $\left(\mathrm{kg} / \mathrm{m}^{3}\right)$ & Particle size distribution $(\mathrm{mm})$ \\
\hline 2710 & 0.3 & 1630 & $5-20$
\end{tabular}

TABLE 4: Concrete mixture proportion.

\begin{tabular}{|c|c|c|c|c|c|c|c|c|}
\hline \multirow[b]{2}{*}{ Mixture } & \multirow[b]{2}{*}{ Cement, $\left(\mathrm{kg} / \mathrm{m}^{3}\right)$} & \multirow[b]{2}{*}{ Water, $\left(\mathrm{kg} / \mathrm{m}^{3}\right)$} & \multicolumn{4}{|c|}{ Aggregate $\left(\mathrm{kg} / \mathrm{m}^{3}\right)$} & \multirow[b]{2}{*}{ Sand $\left(\mathrm{kg} / \mathrm{m}^{3}\right)$} & \multirow{2}{*}{$\begin{array}{l}\text { High-range water- } \\
\text { reducing admixture } \\
\left(\mathrm{kg} / \mathrm{m}^{3}\right)\end{array}$} \\
\hline & & & $\mathrm{w} / \mathrm{c}$ & 5 to $10(\mathrm{~mm})$ & 10 to $16(\mathrm{~mm})$ & 16 to $20(\mathrm{~mm})$ & & \\
\hline $\mathrm{C} 30$ & 378 (no. 42.5 ) & 189 & 0.50 & 491 & 328 & 273 & 758 & 1.89 \\
\hline $\mathrm{C} 40$ & 473 (no. 42.5 ) & 189 & 0.40 & 491 & 328 & 273 & 670 & 3.31 \\
\hline $\mathrm{C} 50$ & 473 (no. 52.5 ) & 189 & 0.40 & 491 & 328 & 273 & 698 & 3.31 \\
\hline C60 & 630 (no. 52.5 ) & 189 & 0.30 & 458 & 305 & 254 & 624 & 5.04 \\
\hline
\end{tabular}

TABLE 5: Size and reinforcement and material properties of tested beams.

\begin{tabular}{|c|c|c|c|c|c|c|c|c|c|c|c|c|}
\hline \multirow{2}{*}{$\begin{array}{l}\text { RC beam } \\
\text { number }\end{array}$} & \multirow{2}{*}{$\begin{array}{l}\text { Width } \\
b / \mathrm{mm}\end{array}$} & \multirow{2}{*}{$\begin{array}{l}\text { Depth } \\
h / \mathrm{mm}\end{array}$} & \multirow{2}{*}{$\begin{array}{c}\text { Effective span } \\
l_{0} / \mathrm{mm}\end{array}$} & \multirow{2}{*}{$\begin{array}{c}\text { Concrete cover } \\
\mathrm{c} / \mathrm{mm}\end{array}$} & \multirow{2}{*}{$\begin{array}{c}\text { Steel ratio } \\
\rho / 100 \%\end{array}$} & \multicolumn{4}{|c|}{ Reinforcement } & \multicolumn{3}{|c|}{ Concrete } \\
\hline & & & & & & $\begin{array}{c}A_{\mathrm{s}} / \\
\mathrm{mm}^{2}\end{array}$ & $\begin{array}{c}f_{\mathrm{y}} / \\
\mathrm{MPa}\end{array}$ & $\begin{array}{c}E_{\mathrm{s}} / \\
\mathrm{GPa}\end{array}$ & $\begin{array}{l}f_{\mathrm{cu}} / \\
\mathrm{MPa}\end{array}$ & $\begin{array}{l}f_{\mathrm{ck}} / \\
\mathrm{MPa}\end{array}$ & $\begin{array}{l}f_{\mathrm{ts}} / \\
\mathrm{MPa}\end{array}$ & $\begin{array}{c}E_{\mathrm{c}} \times 10^{4} / \\
\mathrm{MPa}\end{array}$ \\
\hline $\begin{array}{l}\text { 600-C30-1- } \\
1\end{array}$ & 200 & 350 & 2550 & 30 & 0.8 & 509 & 645.02 & 195 & 37.65 & 26.36 & 1.97 & 3.80 \\
\hline $\begin{array}{l}600-\mathrm{C} 30-1- \\
2\end{array}$ & 200 & 350 & 2550 & 30 & 0.8 & 509 & 645.02 & 195 & 37.65 & 26.36 & 1.97 & 3.80 \\
\hline $\begin{array}{l}600-\mathrm{C} 30-2- \\
1\end{array}$ & 200 & 350 & 2550 & 30 & 0.5 & 308 & 635.71 & 198 & 37.65 & 26.36 & 1.97 & 3.80 \\
\hline $\begin{array}{l}600-\mathrm{C} 30-2- \\
2\end{array}$ & 200 & 350 & 2550 & 30 & 0.5 & 308 & 635.71 & 198 & 37.65 & 26.36 & 1.97 & 3.80 \\
\hline $\begin{array}{l}600-\mathrm{C} 40-1- \\
1\end{array}$ & 200 & 350 & 2550 & 30 & 0.8 & 509 & 645.02 & 195 & 42.55 & 32.19 & 2.69 & 3.70 \\
\hline $\begin{array}{l}600-\mathrm{C} 40-1- \\
2\end{array}$ & 200 & 350 & 2550 & 30 & 0.8 & 509 & 645.02 & 195 & 42.55 & 32.19 & 2.69 & 3.70 \\
\hline $\begin{array}{l}600-\mathrm{C} 40-2- \\
1\end{array}$ & 200 & 350 & 2550 & 30 & 0.5 & 308 & 635.71 & 198 & 42.55 & 32.19 & 2.69 & 3.70 \\
\hline $\begin{array}{l}600-\mathrm{C} 40-2- \\
2\end{array}$ & 200 & 350 & 2550 & 30 & 0.5 & 309 & 635.71 & 198 & 42.55 & 32.19 & 2.69 & 3.70 \\
\hline $\begin{array}{l}600-C 50-1- \\
1\end{array}$ & 200 & 350 & 2550 & 30 & 0.8 & 509 & 645.02 & 195 & 53.00 & 33.28 & 3.40 & 3.70 \\
\hline $\begin{array}{l}600-C 50-1- \\
2\end{array}$ & 200 & 350 & 2550 & 30 & 0.8 & 509 & 645.02 & 195 & 53.00 & 33.28 & 3.40 & 3.70 \\
\hline $\begin{array}{l}600-C 50-2- \\
1\end{array}$ & 200 & 350 & 2550 & 30 & 0.5 & 308 & 635.71 & 198 & 53.00 & 33.28 & 3.40 & 3.70 \\
\hline $\begin{array}{l}600-\mathrm{C} 50-2- \\
2\end{array}$ & 200 & 350 & 2550 & 30 & 0.5 & 308 & 635.71 & 198 & 53.00 & 33.28 & 3.40 & 3.70 \\
\hline $\begin{array}{l}600-\mathrm{C} 60-1- \\
1\end{array}$ & 200 & 350 & 2550 & 30 & 0.8 & 509 & 645.02 & 195 & 67.14 & 62.31 & 3.35 & 4.10 \\
\hline $\begin{array}{l}600-\mathrm{C} 60-1- \\
2\end{array}$ & 200 & 350 & 2550 & 30 & 0.8 & 509 & 645.02 & 195 & 67.14 & 62.31 & 3.35 & 4.10 \\
\hline $\begin{array}{l}600-\mathrm{C} 60-2- \\
1\end{array}$ & 200 & 350 & 2550 & 30 & 0.5 & 308 & 645.02 & 198 & 66.31 & 61.75 & 3.35 & 4.10 \\
\hline $\begin{array}{l}600-\mathrm{C} 60-2- \\
2\end{array}$ & 200 & 350 & 2550 & 30 & 0.5 & 308 & 645.02 & 198 & 66.31 & 61.75 & 3.35 & 4.10 \\
\hline $\begin{array}{l}400-\mathrm{C} 60-1- \\
1\end{array}$ & 200 & 350 & 2550 & 30 & 0.8 & 509 & 428.07 & 200 & 67.14 & 62.31 & 3.35 & 4.10 \\
\hline $\begin{array}{l}400-\mathrm{C} 60-1- \\
2\end{array}$ & 200 & 350 & 2550 & 30 & 0.8 & 509 & 428.07 & 200 & 67.14 & 62.31 & 3.35 & 4.10 \\
\hline
\end{tabular}


tensile strength. Similarly, $f_{\text {ck }}$ (average value from three prisms with the dimensions of $150 \mathrm{~mm} \times 150 \mathrm{~mm} \times 300 \mathrm{~mm}$ ) is the prism compressive strength and $E_{\mathrm{c}}$ (average value from three prisms with the dimensions of $150 \mathrm{~mm} \times 150 \mathrm{~mm}$ $\times 300 \mathrm{~mm}$ ) is the elastic modulus.

2.2. Design and Test of RC Beams. In this experiment, 8 groups ( 2 beams from each group based on the concrete grade) of RC beams were tested. All beams were cast using $600 \mathrm{MPa}$ grade reinforcing steel. 2 RC beams with C60 grade concrete and the steel grade of $400 \mathrm{MPa}$ were cast as a control group. As shown in Figure 1, the two points of the midspan section were symmetrically loaded to form an $800 \mathrm{~mm}$ pure bending section. The load application was based on the design bending moment of the purely bent section. The concrete beam was tested under static loading with consideration of the effects of the beam's own weight and the loading equipment. The load values at all levels were controlled by the readings of the data acquisition system connected to the sensor.

2.3. Stress-Strain Curves of $600 \mathrm{MPa}$ Steel Bar. In this study, $600 \mathrm{MPa}$ grade reinforcement was used as longitudinal reinforcement of the test beam. Figure 3 shows the stressstrain curve of the $600 \mathrm{MPa}$ rebar as obtained from a test. The stress-strain curve of the $600 \mathrm{MPa}$ steel bar shows three stages with a clear yield plateau: elasticity, yielding, and stress hardening. Yield strength $f_{\mathrm{y}}$ and ultimate strength $f_{\mathrm{u}}$ of the $600 \mathrm{MPa}$ rebar with different diameters were between 635.71 MPa and 645.02 $\mathrm{MPa}$, and $819.92 \mathrm{MPa}$ to $840.38 \mathrm{MPa}$, respectively. The Chinese standard GB50010-2010 specifies the measured maximum force total elongation $A_{\mathrm{gt}}$ of steel bars should not be less than $9 \%$. The measured $A_{\mathrm{gt}}$ of 600 MPa grade steel bars was $10.3 \%$.

2.4. Failure Mode and Load-Deformation Curves of RC Beam. The actual failure mode of the RC beam belongs to properreinforced beam failure. As shown in Figure 4, the actual failure state of the test beam is shown that the beam has obvious plastic deformation and fracture precursor before failure. In addition, the load-deformation curves show typical three stage of proper-reinforced beam failure, as shown in Figure 5. The deformation of the specimen increased linearly before cracking. When the external load reached the cracking bending moment $M_{\mathrm{cr}}\left((20 \%-30 \%) M_{\mathrm{u}}\right)$, one or several initial cracks appeared in the pure bending section of the RC beam, the deformation curves exhibited an abrupt transition point, and the slopes of the curves began to decrease. With a further increase in load, when the strength of the $600 \mathrm{MPa}$ steel bar reached its yield strength, the deformation of the specimens increased sharply, a second and more obvious inflection point appeared on the loaddeformation curve, and the concrete in the RC beam was crushed. Therefore, the $600 \mathrm{MPa}$ steel $\mathrm{RC}$ beam is the balanced-reinforced beam.

As shown in Figure 5, when the strength grade of concrete was the same, the bearing capacity of the specimen increased with an increase in reinforcement ratio. On the other hand, the ductility of specimens decreased with an increase in the reinforcement ratio. When the ratio of reinforcement was the same, the bearing capacity of the specimen increased with an increase in the concrete strength grade.

\section{Results and Discussion}

3.1. Analytical Ultimate Bearing Capacity Based on Codes from Various Countries. The calculation methods for the bearing capacity from various Chinese standards are based on the test results of $335 \mathrm{MPa}, 400 \mathrm{MPa}$, and $500 \mathrm{MPa}$ RC beams. Whether the method is applicable to the calculation of the bearing capacity of $600 \mathrm{MPa} \mathrm{RC}$ beams is still uncertain. This needs to be verified based on the test data of $600 \mathrm{MPa} \mathrm{RC}$ beams.

By comparing the bearing capacity equations of various national codes (GB 50010-2010 [24], SL 191-2008 [26],DL/ T5057-2009 [25], JTG D62-2004 [27], ACI 318-2014 [41], EN1992-1-1 [42], CRC Press LLC, 1999 [43], BS5400-4 [44, 45], EN1991-2 [46], and AASHTOLRFD Bridge Design Specification [47]), it can be found that the calculation methods for the bearing capacity of rectangular cross section $\mathrm{RC}$ beams in the current Chinese codes and European and American codes are consistent in expression and symbolic connotation. However, there are subtle differences in the strength calculation and height calculation methods of the concrete equivalent rectangular stress diagram. Therefore, the actual measured value of the bearing capacity of $400 \mathrm{MPa}, 500 \mathrm{MPa}$, and $600 \mathrm{MPa} \mathrm{RC}$ beams and the calculated values based on various codes are compared and analyzed to verify their applicability.

\subsection{Analysis of Moment of Resistance of Beams with $400 \mathrm{MPa}$} Grade Steel. The literature [48-53] reports flexural performance tests of concrete beams reinforced with $400 \mathrm{MPa}$ grade steel, and the relevant information of the specimens is shown in Table 6.

In order to verify the applicability of the bearing capacity equations of the existing national codes, measured flexural bearing capacity of RC beams is compared with the calculated value based on various codes. The comparison of the measured value $M_{\mathrm{u}}$ and the calculated value $M_{\mathrm{uc}}$ is shown in Table 7 and Figure 6. It can be seen that all codes have good accuracy for the calculation of the flexural bearing capacity of concrete beams using $400 \mathrm{MPa}$ grade steel bars $(\mu=1.01-1.17$ and $\delta=0.08-0.1)$.

\subsection{Analysis of Moment of Resistance of Beams with $500 \mathrm{MPa}$} Grade Steel. References [52, 54-60] conducted flexural performance tests of concrete beams reinforced with $500 \mathrm{MPa}$ grade steel. The relevant information of the specimens is shown in Table 8 . In order to verify the applicability of the bearing capacity equations of the existing national codes, measured flexural bearing capacity of RC beams is compared with the calculated value based on various codes. The comparison of the measured value $M_{\mathrm{u}}$ of 

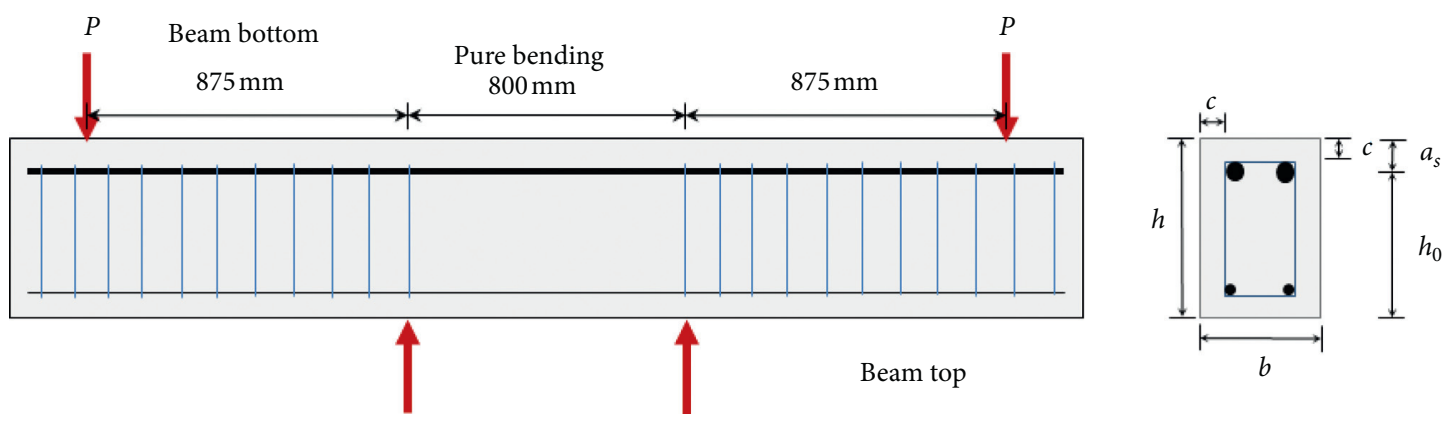

Figure 1: Geometry of RC beams.

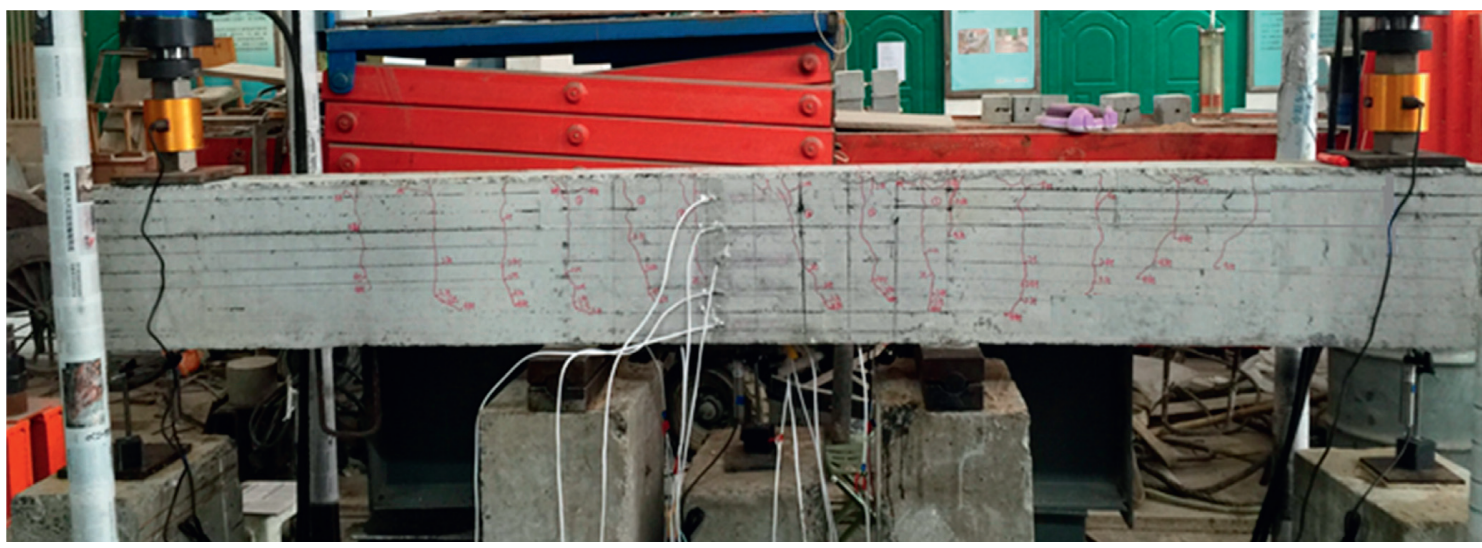

Figure 2: Actual RC beams with $600 \mathrm{MPa}$ steel bars and the test device.

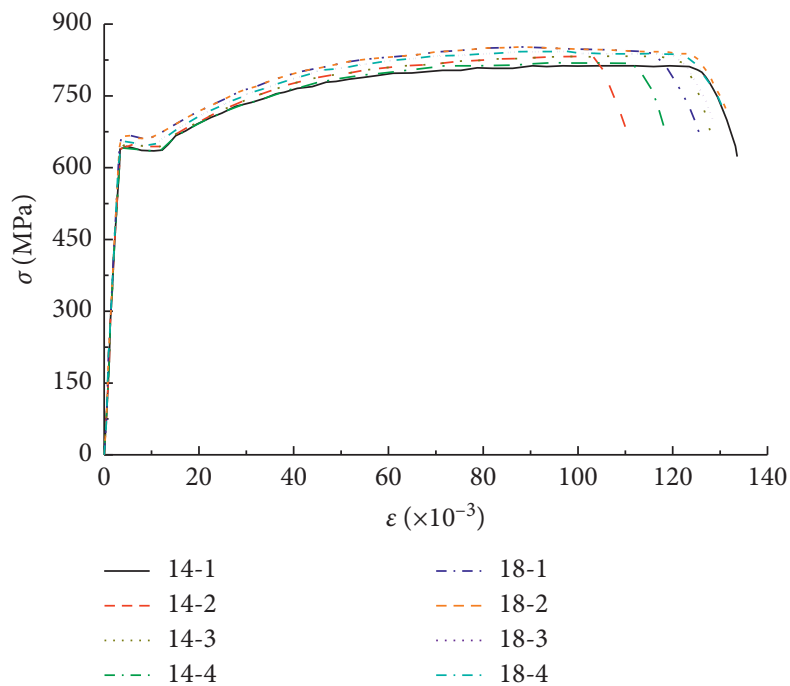

Figure 3: Stress-strain curves of $600 \mathrm{MPa}$ steel bars.

the flexural bearing capacity of the test beams with $500 \mathrm{MPa}$ steel bars and the calculated value $M_{\mathrm{uc}}$ based on different codes is shown in Table 9 and Figure 7. It can be seen that all codes have good accuracy for the calculation of the bending bearing capacity of $500 \mathrm{MPa}$ RC beams $(\mu=1.01-1.22$ and $\delta=0.09-0.11)$.

3.4. Analysis of Moment of Resistance of Beams with $600 \mathrm{MPa}$ Grade Steel. Several studies [39, 52, 53, 61] conducted flexural performance tests of $\mathrm{RC}$ beams reinforced with $600 \mathrm{MPa}$ grade steel. The relevant information of the RC beams in those studies is shown in Table 10. In order to verify the applicability of the bearing capacity equation in the current national standard, results from the experiment in this study are compared with the measured values of the flexural bearing capacity of $\mathrm{RC}$ beams in the literature and with the calculated value based on the national standard. Measured value $M_{u}$ of the flexural bearing capacity of the RC beam reinforced with $600 \mathrm{MPa}$ grade steel is compared with 


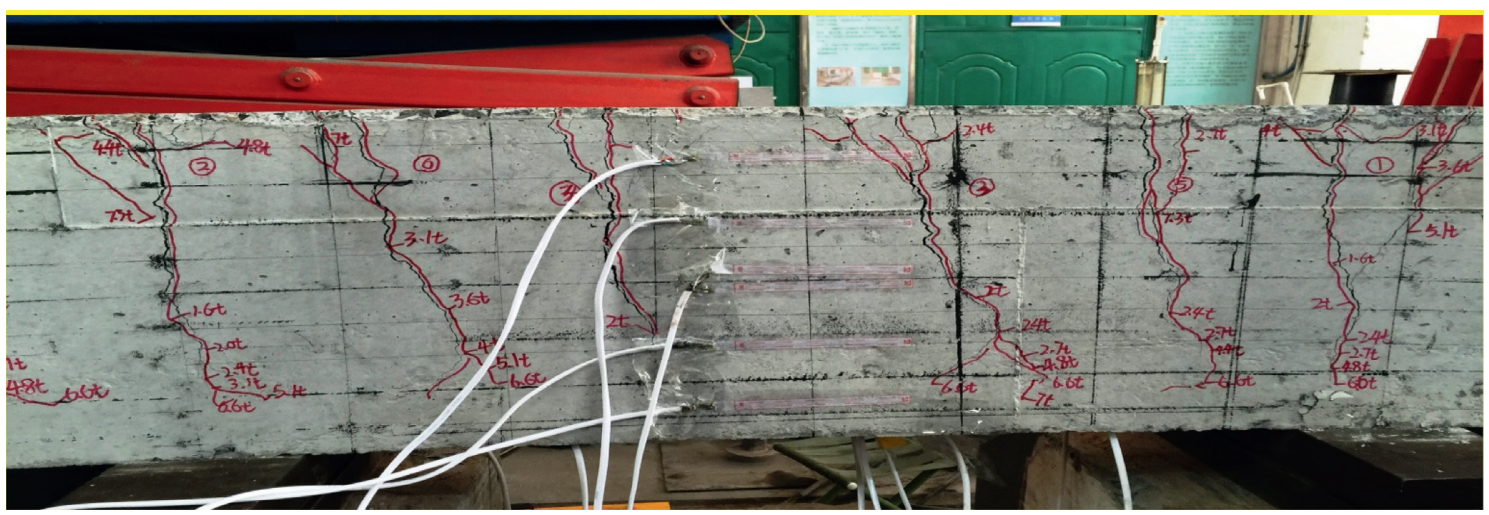

FIgUre 4: Actual failure mode of the RC beam.

the calculated value $M_{\mathrm{uc}}$ based on various codes as shown in Table 11 and Figure 8. Due to the differences in the size of the members designed by different scholars and the properties of the materials used in the experiment and other influencing factors during the experiment, the results have certain differences but the difference is small. The average value $\mu$ of the ratio between the measured value and the calculated value of the ultimate bearing capacity based on the codes is $1.10 \sim 1.27$, and the dispersion coefficient $\delta$ is $0.07 \sim 0.08$. As shown in Figure 8 , the measured values of the ultimate bearing capacity of RC beams with $400 \mathrm{MPa}$ and $500 \mathrm{MPa}$ grade steel are in good agreement with the calculated values of various codes. The data of the configuration of RC beams with $600 \mathrm{MPa}$ grade steel and the configuration of RC beams with $400 \mathrm{MPa}$ and $500 \mathrm{MPa}$ grade steel are similar (the ratio of the measured value of the flexural bearing capacity of RC beams to the calculated values of various codes is around 1.0 for all cases), and the dispersion coefficients are small. In general, the measured value of the ultimate bearing capacity of $600 \mathrm{MPa}$ RC beams coincided with the ultimate bearing capacity calculated from various codes. Therefore, the existing equations in the Chinese code are still applicable to RC beams reinforced with high-strength (600 MPa) steel.

\section{Reliability Analysis of Bearing Capacity}

For an RC beam using $600 \mathrm{MPa}$ grade steel, the design values of the yield strength of reinforcement taken by different scholars are different, such as $500 \mathrm{MPa}$ and $520 \mathrm{MPa}$. In order to determine the appropriate yield strength design value of the $600 \mathrm{MPa}$ grade steel bar in a design specification, this study took the basis of the experiment and the reference standard GB 50010 [24]. The material subentry coefficients as per the standard are 1.1, 1.1, and 1.15, respectively, for the $335 \mathrm{MPa}, 400 \mathrm{MPa}$, and $500 \mathrm{MPa}$ grade steel (yield strength design value of the steel bar determined by many engineering practice and the material subentry coefficient is the ratio of the standard value to the design value of yield strength). Accordingly, the trial design value of the yield strength of $600 \mathrm{MPa}$ grade steel was taken as $500 \mathrm{MPa}$, $520 \mathrm{MPa}$, and $545 \mathrm{MPa}$, corresponding to the material subentry coefficients of $1.1,1.15$, and 1.2 , respectively. Reliability analysis was performed to determine the most appropriate value. On the basis of the experimental study, the reliability analysis of the above three values was carried out to further select the design value of yield strength which would meet the requirements of both strength and reliability.

In the reliability analysis of the flexural bearing capacity of the $600 \mathrm{MPa}$ RC beam, the known function is shown in equation (1), where the structural resistance $R$ obeys the lognormal distribution and the dead load $S_{G}$ obeys the normal distribution. The load $S_{Q}$ obeys the extreme value type I distribution [62]. The most commonly used method for reliability calculation is the first-order second-moment method, including the center point method and the checking point method. The center point method does not take into account the probability distribution of variables, while the JC method (checking point method) can handle other random variables of probability distributions $[63,64]$. In order to consider the probability distribution and correlation of random variables, this paper used the JC method to calculate the reliability of the flexural bearing capacity of $600 \mathrm{MPa}$ RC beams and used MATLAB software to solve the problem:

$$
R-S_{G}-S_{Q}=0 .
$$

4.1. Reliability Index of Beams with Different Yield Strength Values of Steel Bars. In order to select the most suitable design value of the steel bar, the reliability index was calculated for different strength design values for the steel bar. In the process of determining the reliability index, statistical parameters of various loads of $\mathrm{RC}$ beams were referred to the specifications GB 50153 [65] and GB 50009 [66]. The standard value of moment of resistance was calculated by taking the reinforcement strength of $600 \mathrm{MPa}$ and substituting it into the bending bearing capacity formula of GB 50010. Minimum ratio of the dead load to the variable load was determined under the condition that only the selfweight was considered as the dead load. According to the determined calculation parameters, the JC method was used to calculate the reliability index of RC beams.

As shown in Figure 9, for a given constant load to variable load ratio $\rho$, the reliability index of each RC beam was basically the same for different yield strength values of 


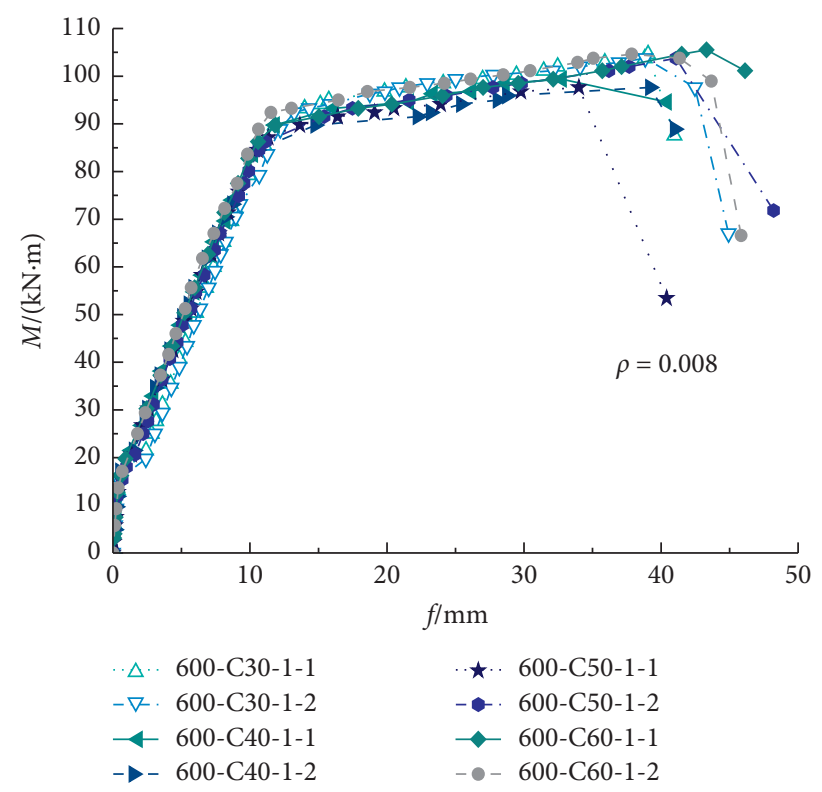

(a)

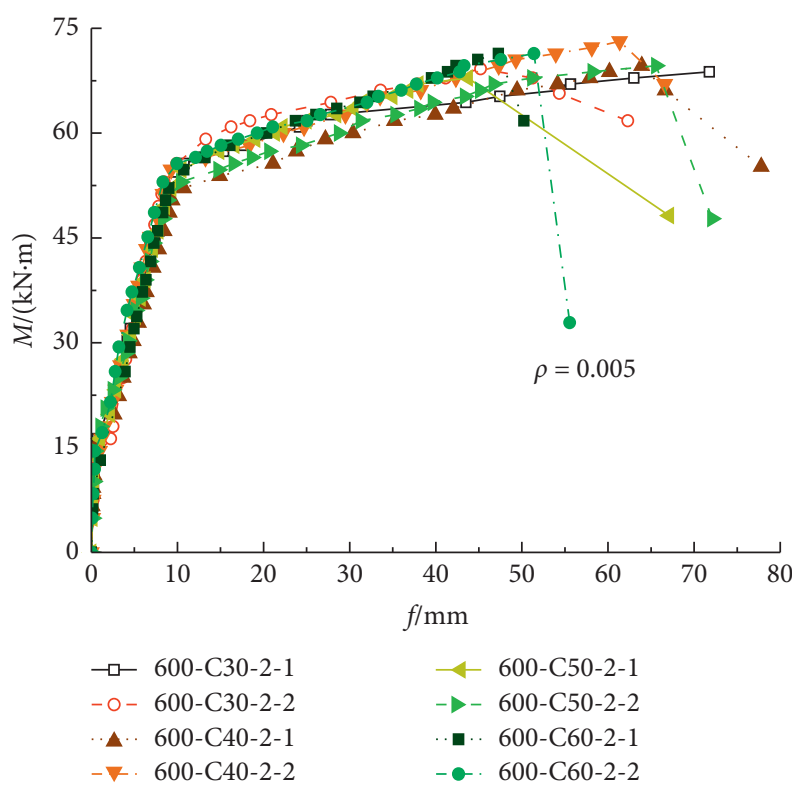

(b)

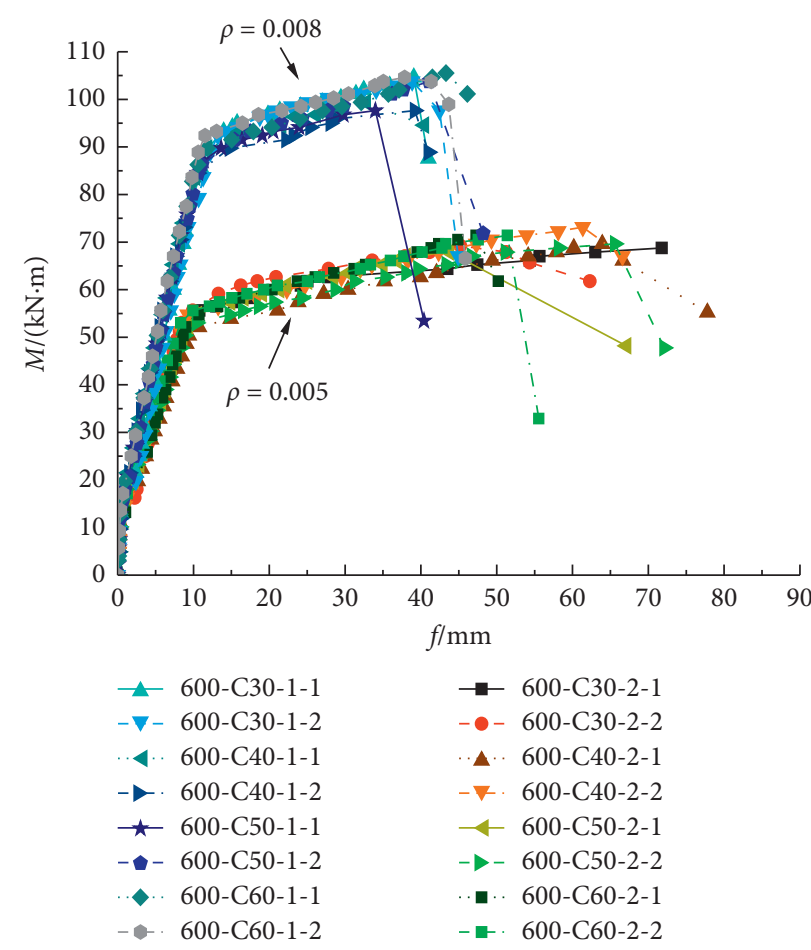

(c)

FIGURE 5: The load-deformation curves for RC beams.

steel. When dead load was the controlling load, that is, when $\rho$ was less than 2.8 , the reliability index of the beam increased continuously with an increase in $\rho$ value and with an increased rate. When the loading was dominated by the variable load, that is, when $\rho$ was greater than 2.8 , the reliability index still increased to a certain extent as the value of $\rho$ increased. When $\rho$ was approximately 7 , the reliability index reached its peak, after which the reliability index decreased marginally and then gradually stabilized. The reliability index of each RC beam was different for different design values of steel yield strength. Generally speaking, the reliability decreased as the design yield strength increased. For the steel with the strength of $600 \mathrm{MPa}$, when the design yield strength was taken as $500 \mathrm{MPa}$, the reliability was the largest and it was followed by $520 \mathrm{MPa}$, and the smallest reliability index was observed corresponding to the yield strength of $545 \mathrm{MPa}$. For beams with a concrete strength grade of C60, two types of steel bars, namely, HRB600 and 
TABle 6: Details of beams with $400 \mathrm{MPa}$ steel bars.

\begin{tabular}{|c|c|c|c|c|c|c|c|c|c|c|c|c|c|}
\hline \multirow{2}{*}{$\begin{array}{l}\text { Data } \\
\text { sources }\end{array}$} & \multirow{2}{*}{$\begin{array}{c}\text { RC beam } \\
\text { number }\end{array}$} & \multirow{2}{*}{$b / \mathrm{mm}$} & \multirow{2}{*}{$h / \mathrm{mm}$} & \multirow{2}{*}{$l_{0} / \mathrm{mm}$} & \multirow{2}{*}{$c / \mathrm{mm}$} & \multirow{2}{*}{$\rho / 100 \%$} & \multicolumn{4}{|c|}{ Reinforcement } & \multicolumn{3}{|c|}{ Concrete } \\
\hline & & & & & & & $A_{\mathrm{s}} / \mathrm{mm}^{2}$ & fy/MPa & Es/GPa & $F c u / M P a$ & $F c k / M P a$ & $\mathrm{fts} / \mathrm{MPa}$ & $E c \times 104 / \mathrm{MPa}$ \\
\hline \multirow{3}{*}[48]{} & SB-1 & 200 & 400 & 2210 & 30 & 0.9 & 628 & 470 & 200 & 18.80 & 14.30 & 1.99 & 2.47 \\
\hline & SB-2 & 200 & 400 & 2210 & 30 & 0.7 & 509 & 533 & 200 & 23.50 & 17.90 & 2.24 & 2.72 \\
\hline & SB-3 & 200 & 400 & 2210 & 30 & 0.6 & 461 & 493 & 200 & 15.50 & 11.80 & 1.78 & 2.25 \\
\hline \multirow{6}{*}{ [49] } & L-1 & 200 & 400 & 3300 & 30 & 0.9 & 628 & 450 & 200 & 29.67 & 19.84 & 1.42 & 2.97 \\
\hline & L-2 & 200 & 400 & 3300 & 30 & 1.3 & 928 & 455 & 200 & 33.53 & 22.42 & 1.48 & 3.09 \\
\hline & L-3 & 200 & 400 & 3300 & 30 & 1.3 & 942 & 457 & 200 & 24.32 & 16.26 & 1.25 & 2.76 \\
\hline & $\mathrm{L}-4$ & 200 & 400 & 3300 & 30 & 0.9 & 628 & 485 & 200 & 27.64 & 18.48 & 1.36 & 2.89 \\
\hline & TL-1 & 200 & 400 & 4300 & 30 & 0.9 & 628 & 465 & 200 & 27.38 & 18.50 & 1.36 & 2.88 \\
\hline & TL-2 & 200 & 400 & 4300 & 30 & 0.9 & 628 & 475 & 200 & 22.22 & 14.68 & 1.18 & 2.66 \\
\hline \multirow{6}{*}{ [50] } & L-1 & 152 & 304 & 1800 & 30 & 0.5 & 226 & 504 & 200 & 47.75 & 28.64 & 2.44 & 3.32 \\
\hline & L-2 & 150 & 304 & 1800 & 30 & 0.8 & 339 & 504 & 200 & 40.90 & 27.50 & 2.38 & 3.28 \\
\hline & L-3 & 153 & 305 & 1800 & 30 & 1.2 & 509 & 479 & 200 & 42.75 & 28.64 & 2.44 & 3.32 \\
\hline & L-4 & 150 & 305 & 1800 & 30 & 1.2 & 509 & 458 & 200 & 41.00 & 27.47 & 2.38 & 3.28 \\
\hline & L-5 & 151 & 304 & 1800 & 30 & - & 308 & 448 & 200 & 42.80 & 28.68 & 2.44 & 3.32 \\
\hline & L-6 & 149 & 305 & 1800 & 30 & 1.3 & 509 & 479 & 200 & 44.60 & 29.88 & 2.50 & 3.36 \\
\hline \multirow{4}{*}{ [51] } & B4A & 180 & 300 & 3000 & 30 & 0.5 & 226 & 405 & - & 41.60 & 27.8 & 2.8 & 3.31 \\
\hline & $\mathrm{B} 4 \mathrm{~B}$ & 180 & 300 & 3000 & 30 & 0.7 & 339 & 405 & - & 41.60 & 27.8 & 2.8 & 3.31 \\
\hline & $\mathrm{B} 4 \mathrm{C}$ & 180 & 300 & 3000 & 30 & 1.1 & 515 & 452 & - & 41.60 & 27.8 & 2.8 & 3.31 \\
\hline & B4D & 180 & 300 & 3000 & 30 & 1.5 & 716 & 452 & - & 41.60 & 27.8 & 2.8 & 3.31 \\
\hline \multirow{3}{*}{ [52] } & L7 & 250 & 400 & 3400 & 35 & 1.5 & 1521 & 360 & 200 & - & 14.3 & 1.432 & 3.0 \\
\hline & L8 & 250 & 400 & 3400 & 35 & 1.5 & 1521 & 360 & & - & 23.1 & 1.89 & 3.45 \\
\hline & L9 & 250 & 400 & 3400 & 35 & 1.5 & 1521 & 360 & 200 & - & 27.5 & 2.04 & 3.6 \\
\hline [53] & LW-5 & 200 & 400 & 3000 & 25 & 2.0 & 1473 & 445 & - & 29.1 & 19.5 & 2.22 & - \\
\hline
\end{tabular}

Note. Symbol "-" means that the parameter has no relevant data in the literature.

HRB400, were used. The curve of the reliability of RC beams with $\rho$ value is shown in Figure 10. When the design yield strength of the HRB600 steel bar was taken as $500 \mathrm{MPa}$ and $520 \mathrm{MPa}$, the reliability of the beam was greater than that when the HRB400 steel bar was used. However, when the design yield strength of the HRB600 steel bar was $545 \mathrm{MPa}$, the reliability of the beam was less than that of the beam using the HRB400 steel bar.

The minimum reliability index can reflect the reliability performance of the component under the most unfavorable conditions, so statistical analysis was necessary to determine the minimum reliability index of the beam. Table 12 shows the minimum value of the reliability index of the C60 test beams under different conditions. For C60 beams equipped with HRB600 steel bars, the minimum reliability index corresponding to the reinforcement ratio of 0.005 was greater than the index corresponding to the reinforcement ratio of 0.008 . For a given reinforcement ratio, the minimum reliability index decreased with an increase in the design yield strength of the steel bar. This study calculated the average value of the minimum reliability index corresponding to HRB600 RC beams under different reinforcement ratios. When the design yield strength was $520 \mathrm{MPa}$, the minimum reliability index average value was 3.172 , which is closest to the code specified value and basically meets the reliability criterion. The failure probabilities of the HRB400 RC beam and that of the HRB600 RC beam with the design yield strength of $500 \mathrm{MPa}$ and $520 \mathrm{MPa}$ were comparable to the standard failure probability. When the design yield strength of the HRB600 steel bar was taken as $545 \mathrm{MPa}$, the beam's failure probability was an order of magnitude smaller than the normative failure probability.

When designing the bearing capacity of a beam, considering that the beam should have sufficient safety protection, the design value of the bearing capacity of the component is generally less than the ultimate bearing capacity. Table 13 compares the measured value of the bearing capacity for all test beams with the calculated value when design yield strength of the steel bars was taken as $520 \mathrm{MPa}$. As shown in the table, the calculated value of the ultimate bearing capacity of each test beam obtained from the existing Chinese code <cite $>$ equation is less than the actual measured value of the ultimate bearing capacity, demonstrating a larger safety reserve $(\mu=1.36 \sim 1.59$ and $\delta=0.05 \sim 0.06$ ).

On the basis of the experiment and practice, $500 \mathrm{MPa}$, $520 \mathrm{MPa}$, and $545 \mathrm{MPa}$ were selected as the possibly appropriate design value of yield strength of the $600 \mathrm{MPa}$ grade reinforcement. Reliability analysis showed that $500 \mathrm{MPa}$ and $520 \mathrm{MPa}$ met the reliability requirements. Moreover, use of $520 \mathrm{MPa}$ as the design value showed a large strength surplus 
TABLE 7: Comparison of experimental flexural bearing capacity $M_{\mathrm{u}}$ with $M_{\mathrm{uc}}$ calculated by different codes for beams with $400 \mathrm{MPa}$ steel bars.

\begin{tabular}{|c|c|c|c|c|c|c|}
\hline Data sources & $\mathrm{RC}$ beam number & $\begin{array}{c}\text { GB50010-2010 } \\
M_{\mathrm{u}} / M_{\mathrm{uc}} \\
\end{array}$ & $\begin{array}{c}\text { SL191-2008 } \\
M_{\mathrm{u}} / M_{\mathrm{uc}}\end{array}$ & $\begin{array}{c}\mathrm{DL} / \mathrm{T} 5057-2009 \\
M_{\mathrm{u}} / M_{\mathrm{uc}} \\
\end{array}$ & $\begin{array}{c}\text { JTGD62-2012 } \\
M_{\mathrm{u}} / M_{\mathrm{uc}} \\
\end{array}$ & $\begin{array}{c}\mathrm{ACI} 318-2014 \\
M_{\mathrm{u}} / M_{\mathrm{uc}}\end{array}$ \\
\hline \multirow{2}{*}{ Test } & $400-\mathrm{C} 60-1-1$ & 1.14 & 1.14 & 1.14 & 1.14 & 1.14 \\
\hline & $400-\mathrm{C} 60-1-2$ & 1.07 & 1.07 & 1.07 & 1.07 & 1.07 \\
\hline \multirow{3}{*}[48]{} & SB-1 & 1.17 & 1.17 & 1.17 & 1.17 & 1.21 \\
\hline & SB-2 & 0.98 & 0.98 & 0.98 & 0.98 & 1.00 \\
\hline & SB-3 & 1.06 & 1.06 & 1.06 & 1.06 & 1.09 \\
\hline \multirow{6}{*}{ [49] } & L-1 & 0.97 & 0.97 & 0.97 & 0.97 & 0.99 \\
\hline & L-2 & 0.95 & 0.95 & 0.95 & 0.95 & 0.98 \\
\hline & L-3 & 0.99 & 0.99 & 0.99 & 0.99 & 1.03 \\
\hline & $\mathrm{L}-4$ & 1.00 & 1.00 & 1.00 & 1.00 & 1.02 \\
\hline & TL-1 & 1.06 & 1.06 & 1.06 & 1.06 & 1.08 \\
\hline & TL-2 & 1.10 & 1.10 & 1.10 & 1.10 & 1.13 \\
\hline \multirow{6}{*}[50]{} & L-1 & 1.09 & 1.09 & 1.09 & 1.09 & 1.10 \\
\hline & $\mathrm{L}-2$ & 1.09 & 1.09 & 1.09 & 1.09 & 1.11 \\
\hline & $\mathrm{L}-3$ & 1.04 & 1.04 & 1.04 & 1.04 & 1.06 \\
\hline & $\mathrm{L}-4$ & 1.08 & 1.08 & 1.08 & 1.08 & 1.10 \\
\hline & $\mathrm{L}-5$ & 1.08 & 1.08 & 1.08 & 1.08 & 1.09 \\
\hline & $\mathrm{L}-6$ & 1.12 & 1.12 & 1.12 & 1.12 & 1.14 \\
\hline \multirow{4}{*}[51]{} & $\mathrm{B} 4 \mathrm{~A}$ & 0.98 & 0.98 & 0.98 & 0.98 & 0.99 \\
\hline & $\mathrm{B} 4 \mathrm{~B}$ & 0.93 & 0.93 & 0.93 & 0.93 & 0.94 \\
\hline & $\mathrm{B} 4 \mathrm{C}$ & 0.89 & 0.89 & 0.89 & 0.89 & 0.90 \\
\hline & $\mathrm{B} 4 \mathrm{D}$ & 0.93 & 0.93 & 0.93 & 0.93 & 0.95 \\
\hline \multirow{3}{*}[52]{} & L7 & 0.90 & 0.90 & 0.90 & 0.90 & 0.95 \\
\hline & L8 & 0.89 & 0.89 & 0.89 & 0.89 & 0.91 \\
\hline & L9 & 0.88 & 0.88 & 0.88 & 0.88 & 0.90 \\
\hline [53] & LW-5 & 1.10 & 1.10 & 1.10 & 1.10 & 1.16 \\
\hline$\mu$ & - & 1.02 & 1.02 & 1.02 & 1.02 & 1.04 \\
\hline$\delta$ & - & 0.08 & 0.08 & 0.08 & 0.08 & 0.08 \\
\hline \multirow{2}{*}{ Data sources } & & EN 1992-1-1 & BS5400-4 & AASHEO & EN1991-2 2003 & CRC PRESS \\
\hline & RC beam number & $M_{\mathrm{u}} / M_{\mathrm{uc}}$ & $M_{\mathrm{u}} / M_{\mathrm{uc}}$ & $M_{\mathrm{u}} / M_{\mathrm{uc}}$ & $M_{\mathrm{u}} / M_{\mathrm{uc}}$ & $M_{\mathrm{u}} / M_{\mathrm{uc}}$ \\
\hline \multirow{2}{*}{ Test } & 400-C60-1-1 & 1.23 & 1.31 & 1.14 & 1.14 & 1.14 \\
\hline & $400-C 60-1-2$ & 1.15 & 1.22 & 1.07 & 1.06 & 1.07 \\
\hline \multirow{3}{*}[48]{} & SB-1 & 1.17 & 1.35 & 1.21 & 1.17 & 1.21 \\
\hline & SB-2 & 0.98 & 1.13 & 1.00 & 0.98 & 1.00 \\
\hline & SB-3 & 1.06 & 1.22 & 1.09 & 1.06 & 1.09 \\
\hline \multirow{6}{*}{ [49] } & $\mathrm{L}-1$ & 0.97 & 1.12 & 0.99 & 0.97 & 0.99 \\
\hline & L-2 & 0.95 & 1.09 & 0.98 & 0.95 & 0.98 \\
\hline & L-3 & 0.99 & 1.14 & 1.03 & 0.99 & 1.03 \\
\hline & $\mathrm{L}-4$ & 1.00 & 1.15 & 1.02 & 1.00 & 1.02 \\
\hline & TL-1 & 1.06 & 1.21 & 1.08 & 1.06 & 1.08 \\
\hline & TL-2 & 1.10 & 1.26 & 1.13 & 1.10 & 1.13 \\
\hline \multirow{6}{*}{ [50] } & L-1 & 1.09 & 1.25 & 1.10 & 1.09 & 1.10 \\
\hline & L-2 & 1.09 & 1.25 & 1.11 & 1.09 & 1.11 \\
\hline & L-3 & 1.04 & 1.19 & 1.06 & 1.04 & 1.06 \\
\hline & L-4 & 1.08 & 1.24 & 1.10 & 1.08 & 1.10 \\
\hline & L-5 & 1.08 & 1.24 & 1.09 & 1.08 & 1.09 \\
\hline & L-6 & 1.12 & 1.29 & 1.14 & 1.12 & 1.14 \\
\hline \multirow{4}{*}{ [51] } & $\mathrm{B} 4 \mathrm{~A}$ & 0.98 & 1.13 & 0.99 & 0.95 & 0.99 \\
\hline & B4B & 0.93 & 1.07 & 0.94 & 0.88 & 0.94 \\
\hline & B4C & 0.89 & 1.02 & 0.90 & 0.81 & 0.90 \\
\hline & B4D & 0.93 & 1.07 & 0.95 & 0.82 & 0.95 \\
\hline \multirow{3}{*}{ [52] } & L7 & 0.90 & 1.04 & 0.95 & 0.90 & 0.95 \\
\hline & L8 & 0.89 & 1.02 & 0.91 & 0.89 & 0.91 \\
\hline & L9 & 0.88 & 1.01 & 0.90 & 0.88 & 0.90 \\
\hline [53] & LW-5 & 1.10 & 1.15 & 1.16 & 1.13 & 0.98 \\
\hline $\bar{\mu}$ & - & 1.03 & 1.17 & 1.04 & 1.01 & 1.04 \\
\hline$\delta$ & - & 0.09 & 0.08 & 0.08 & 0.10 & 0.08 \\
\hline
\end{tabular}

Note. $M_{\mathrm{u}}$ in the table is the measured ultimate flexural bearing capacity and $M_{\mathrm{uc}}$ is the calculated value of ultimate flexural bearing capacity obtained by taking the measured yield strength of reinforcement from the current code formulas. 


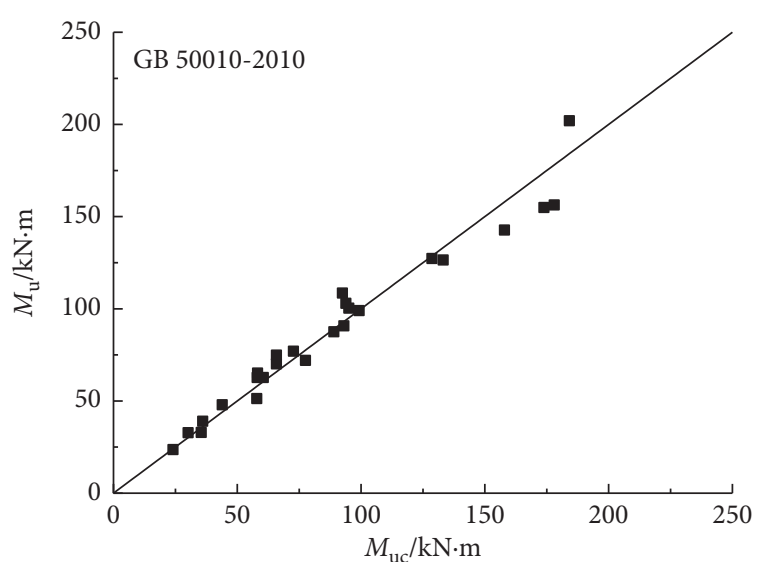

(a)

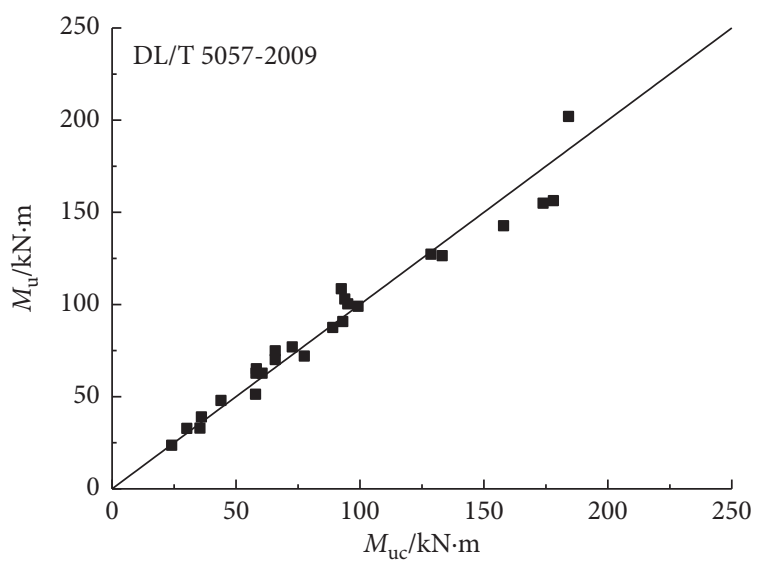

(c)

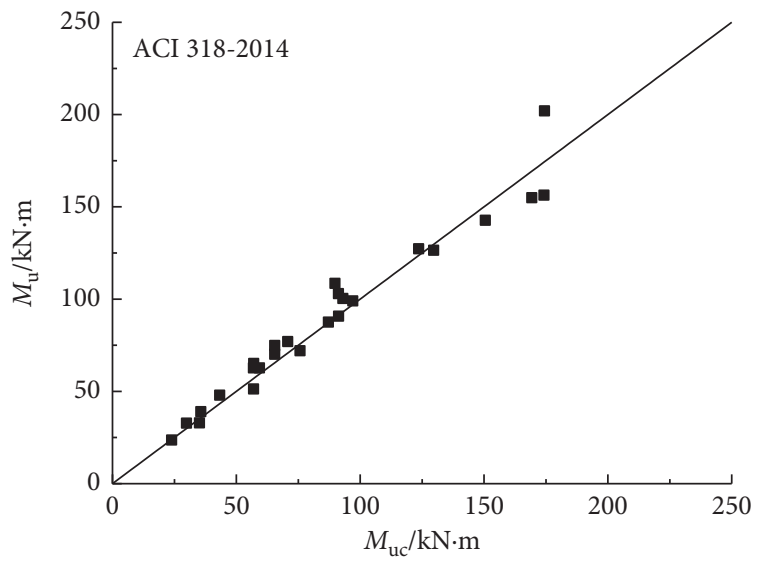

(e)

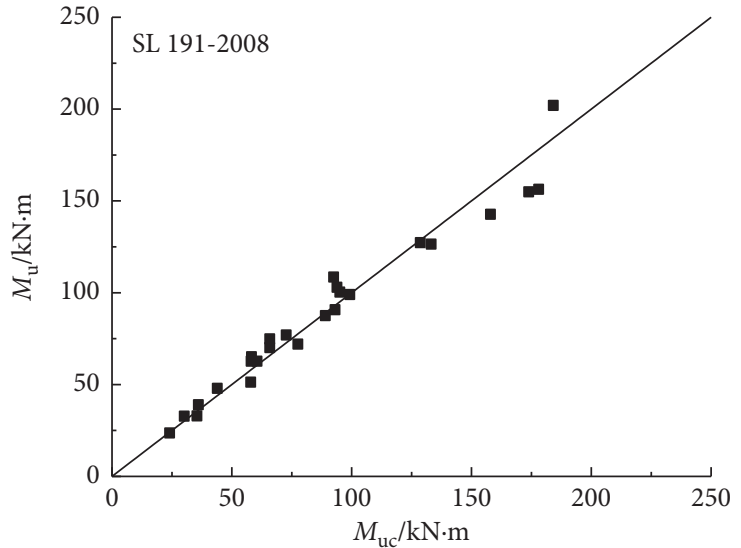

(b)

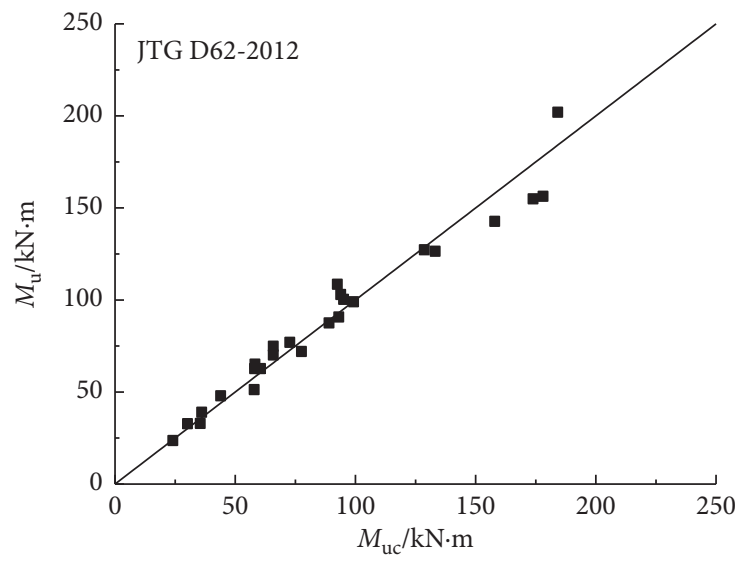

(d)

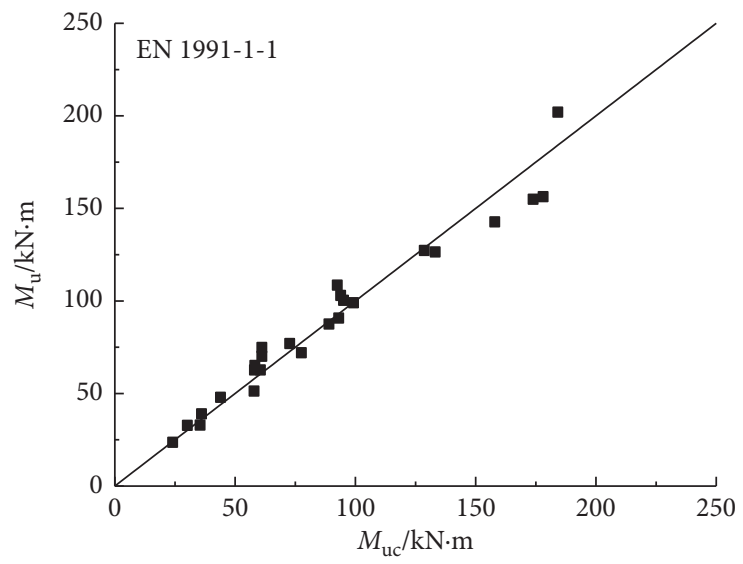

(f)

Figure 6: Continued. 


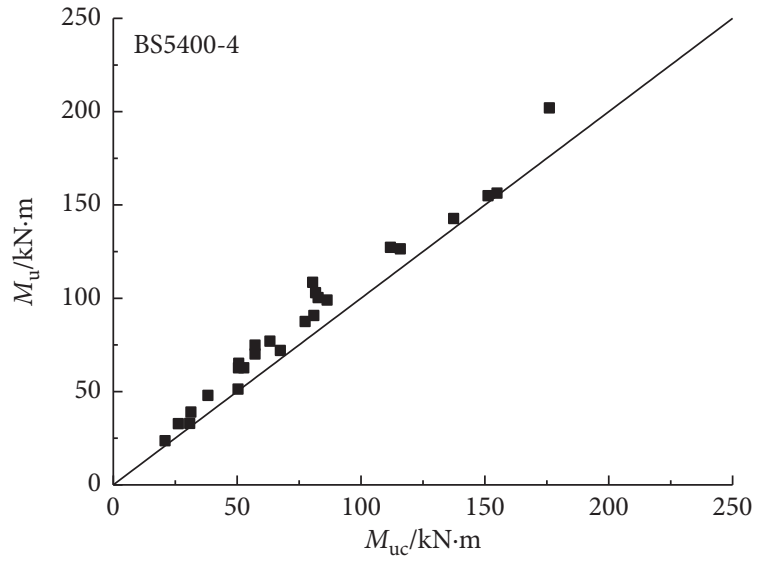

(g)

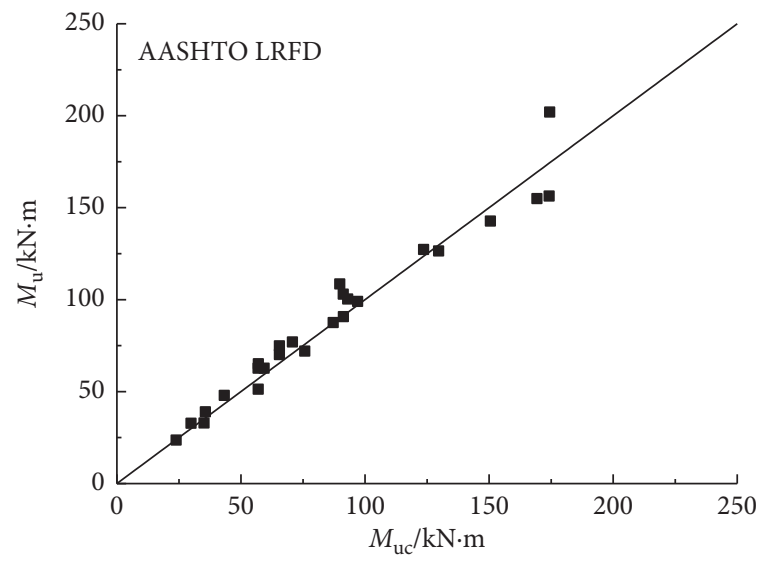

(i)

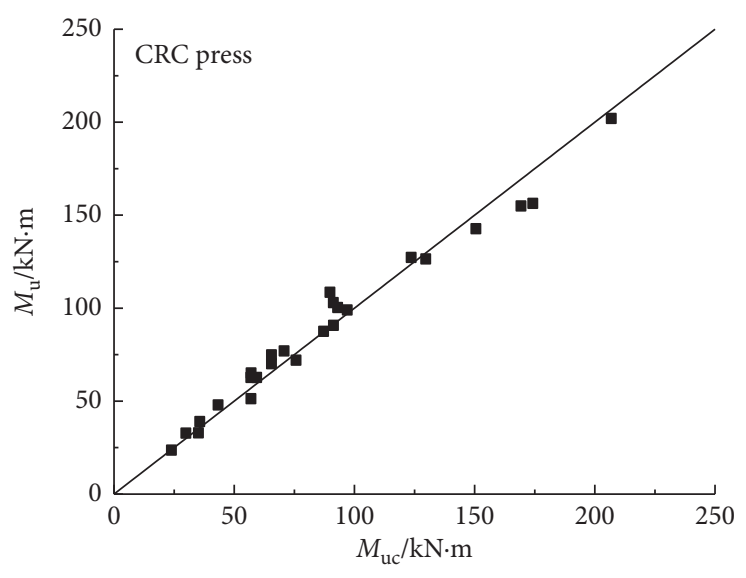

(h)

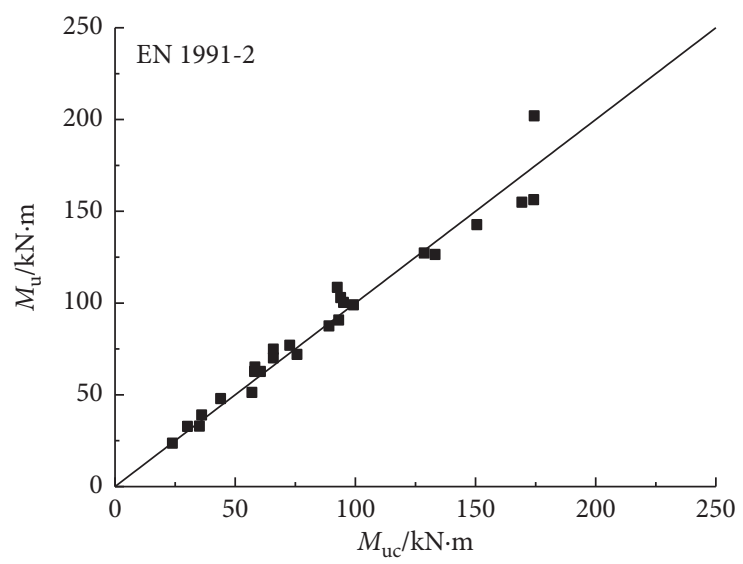

(j)

Figure 6: Comparison of experimental flexural bearing capacity $M_{\mathrm{u}}$ with $M_{\mathrm{uc}}$ calculated by different codes for beams with $400 \mathrm{MPa}$ steel bars.

TABLE 8: Details of beams with $500 \mathrm{MPa}$ steel bars.

\begin{tabular}{|c|c|c|c|c|c|c|c|c|c|c|c|c|c|}
\hline \multirow{2}{*}{$\begin{array}{l}\text { Data } \\
\text { sources }\end{array}$} & \multirow{2}{*}{$\begin{array}{l}\text { RC beam } \\
\text { number }\end{array}$} & \multirow{2}{*}{$b / \mathrm{mm}$} & \multirow{2}{*}{$h / \mathrm{mm}$} & \multirow{2}{*}{$10 / \mathrm{mm}$} & \multirow{2}{*}{$c / \mathrm{mm}$} & \multirow{2}{*}{$\rho / 100 \%$} & \multicolumn{3}{|c|}{ Reinforcement } & \multicolumn{4}{|c|}{ Concrete } \\
\hline & & & & & & & $A_{\mathrm{s}} / \mathrm{mm}^{2}$ & $f_{\mathrm{y}} / \mathrm{MPa}$ & $E_{\mathrm{s}} / \mathrm{GPa}$ & $f_{\mathrm{cu}} / \mathrm{MPa}$ & $f_{\mathrm{ck}} / \mathrm{MPa}$ & $f_{\mathrm{ts}} / \mathrm{MPa}$ & $E_{\mathrm{c}} \times 10^{4} / \mathrm{MPa}$ \\
\hline \multirow{7}{*}{ [54] } & LW1 & 200 & 400 & 3200 & 30 & 0.8 & 603 & 567.3 & 210 & 43.4 & 27.3 & 2.66 & 3.33 \\
\hline & LW2 & 200 & 400 & 3200 & 30 & 0.8 & 603 & 567.3 & 210 & 47.8 & 30.4 & 2.79 & 3.42 \\
\hline & LW3 & 200 & 400 & 3200 & 30 & 0.8 & 603 & 567.3 & 210 & 56.2 & 34.3 & 2.97 & 3.55 \\
\hline & LW4 & 200 & 400 & 3200 & 30 & 1.3 & 982 & 502.8 & 210 & 43.4 & 27.3 & 2.66 & 3.33 \\
\hline & LW5 & 200 & 400 & 3200 & 30 & 1.3 & 982 & 502.8 & 210 & 47.8 & 30.4 & 2.79 & 3.42 \\
\hline & LW6 & 200 & 400 & 3200 & 30 & 1.3 & 982 & 502.8 & 210 & 56.2 & 34.3 & 2.97 & 3.55 \\
\hline & LW7 & 200 & 400 & 3200 & 30 & 2.1 & 1608 & 522.5 & 210 & 47.8 & 30.4 & 2.79 & 3.42 \\
\hline \multirow{9}{*}{ [55] } & FB1 & 200 & 400 & 3000 & 30 & 0.4 & 339 & 515 & 211 & 23.3 & 15.6 & 1.96 & 2.71 \\
\hline & FB2 & 200 & 410 & 3000 & 30 & 0.6 & 509 & 567 & 213 & 28.1 & 18.8 & 2.18 & 2.91 \\
\hline & FB3 & 200 & 399 & 3000 & 30 & 1.2 & 982 & 537 & 205 & 25.7 & 17.2 & 2.07 & 2.82 \\
\hline & FB4 & 200 & 403 & 3000 & 30 & 0.4 & 339 & 515 & 211 & 33.4 & 22.3 & 2.39 & 3.09 \\
\hline & FB5 & 200 & 401 & 3000 & 30 & 0.6 & 509 & 567 & 213 & 33.5 & 22.4 & 2.4 & 3.09 \\
\hline & FB6 & 200 & 405 & 3000 & 30 & 1.2 & 982 & 537 & 205 & 32.1 & 21.5 & 2.34 & 3.05 \\
\hline & FB7 & 200 & 395 & 3000 & 30 & 0.4 & 339 & 515 & 211 & 40.6 & 27.1 & 2.67 & 3.27 \\
\hline & FB8 & 200 & 406 & 3000 & 30 & 0.6 & 509 & 567 & 213 & 40.7 & 27.2 & 2.67 & 3.28 \\
\hline & FB9 & 200 & 402 & 3000 & 30 & 1.2 & 982 & 537 & 205 & 40.3 & 27 & 2.65 & 3.27 \\
\hline \multirow{4}{*}{ [56] } & B5F1 & 250 & 400 & 3600 & 30 & 0.7 & 603 & 549.5 & 200 & - & 22.74 & 2.16 & 3.11 \\
\hline & B5F2 & 250 & 400 & 3600 & 30 & 1.1 & 982 & 495 & 200 & - & 22.74 & 2.16 & 3.11 \\
\hline & B5F3 & 250 & 400 & 3600 & 30 & 0.7 & 603 & 549.5 & 200 & - & 36.2 & 2.77 & 3.55 \\
\hline & B5F4 & 250 & 400 & 3600 & 30 & 1.1 & 982 & 495 & 200 & - & 36.2 & 2.77 & 3.55 \\
\hline
\end{tabular}


TABLE 8: Continued.

\begin{tabular}{|c|c|c|c|c|c|c|c|c|c|c|c|c|c|}
\hline \multirow{2}{*}{$\begin{array}{l}\text { Data } \\
\text { sources }\end{array}$} & \multirow{2}{*}{$\begin{array}{l}\text { RC beam } \\
\text { number }\end{array}$} & \multirow{2}{*}{$b / \mathrm{mm}$} & \multirow{2}{*}{$h / \mathrm{mm}$} & \multirow{2}{*}{$l 0 / \mathrm{mm}$} & \multirow{2}{*}{$c / \mathrm{mm}$} & \multirow{2}{*}{$\rho / 100 \%$} & \multicolumn{3}{|c|}{ Reinforcement } & \multicolumn{4}{|c|}{ Concrete } \\
\hline & & & & & & & $A_{\mathrm{s}} / \mathrm{mm}^{2}$ & $f_{\mathrm{y}} / \mathrm{MPa}$ & $E_{\mathrm{s}} / \mathrm{GPa}$ & $f_{\mathrm{cu}} / \mathrm{MPa}$ & $f_{\mathrm{ck}} / \mathrm{MPa}$ & $f_{\mathrm{ts}} / \mathrm{MPa}$ & $E_{\mathrm{c}} \times 10^{4} / \mathrm{MPa}$ \\
\hline \multirow{7}{*}{ [57] } & LW1 & 204 & 400 & 3200 & 30 & 0.8 & 603 & 567.3 & 200 & 41.3 & 27.3 & 2.66 & 3.29 \\
\hline & LW2 & 202 & 400 & 3200 & 30 & 0.8 & 603 & 567.3 & 200 & 45.5 & 30 & 2.79 & 3.38 \\
\hline & LW3 & 202 & 400 & 3200 & 30 & 0.8 & 603 & 567.3 & 200 & 53.5 & 34.3 & 2.97 & 3.51 \\
\hline & LW4 & 199 & 400 & 3200 & 30 & 1.3 & 982 & 502.8 & 200 & 41.3 & 27.3 & 2.66 & 3.29 \\
\hline & LW5 & 200 & 400 & 3200 & 30 & 1.3 & 982 & 502.8 & 200 & 45.5 & 30 & 2.79 & 3.38 \\
\hline & LW6 & 199 & 400 & 3200 & 30 & 1.3 & 982 & 502.8 & 200 & 53.5 & 34.3 & 2.97 & 3.51 \\
\hline & LW7 & 200 & 400 & 3200 & 30 & 2.2 & 1608 & 522.5 & 200 & 45.5 & 30 & 2.79 & 3.38 \\
\hline \multirow{12}{*}{ [58] } & L1 & 202 & 405 & 3200 & 30 & 0.6 & 462 & 525 & 200 & 21.42 & 14.33 & 1.87 & 2.62 \\
\hline & $\mathrm{L} 2$ & 204 & 400 & 3200 & 30 & 0.8 & 603 & 550 & 200 & 21.42 & 14.33 & 1.87 & 2.62 \\
\hline & L3 & 198 & 401 & 3200 & 30 & 1.0 & 760 & 530 & 200 & 21.42 & 14.33 & 1.87 & 2.62 \\
\hline & $\mathrm{L} 4$ & 201 & 402 & 3200 & 30 & 1.3 & 982 & 505 & 200 & 21.42 & 14.33 & 1.87 & 2.62 \\
\hline & LX1-A & 200 & 402 & 3200 & 30 & 0.6 & 462 & 525 & 200 & 22.1 & 14.78 & 1.91 & 2.65 \\
\hline & LX2-A & 199 & 402 & 3200 & 30 & 0.8 & 603 & 550 & 200 & 22.1 & 14.78 & 1.91 & 2.65 \\
\hline & LX3-A & 202 & 400 & 3200 & 30 & 1.0 & 760 & 530 & 200 & 22.1 & 14.78 & 1.91 & 2.65 \\
\hline & LX4-A & 201 & 403 & 3200 & 30 & 1.3 & 982 & 505 & 200 & 22.1 & 14.78 & 1.91 & 2.65 \\
\hline & LX1-B & 203 & 402 & 3200 & 30 & 0.6 & 462 & 525 & 200 & 21.01 & 14.05 & 1.86 & 2.6 \\
\hline & LX2-B & 200 & 401 & 3200 & 30 & 0.8 & 603 & 550 & 200 & 21.01 & 14.05 & 1.86 & 2.6 \\
\hline & LX3-B & 203 & 400 & 3200 & 30 & 1.0 & 760 & 530 & 200 & 21.01 & 14.05 & 1.86 & 2.6 \\
\hline & LX4-B & 202 & 401 & 3200 & 30 & 1.3 & 982 & 505 & 200 & 21.01 & 14.05 & 1.86 & 2.6 \\
\hline \multirow{11}{*}{ [59] } & L1-A & 149 & 305 & 2800 & 30 & 0.2 & 100 & 540 & 200 & 27.96 & 18.7 & 2.47 & 2.91 \\
\hline & L1-B & 253 & 305 & 2800 & 30 & 0.2 & 100 & 540 & 200 & 27.96 & 18.7 & 2.47 & 2.91 \\
\hline & L1-C & 150 & 303 & 2800 & 30 & 0.2 & 100 & 540 & 200 & 42.67 & 28.54 & 3.11 & 3.32 \\
\hline & L2-A & 152 & 310 & 2800 & 30 & 1.0 & 399 & 502 & 200 & 46.31 & 30.97 & 3.26 & 3.39 \\
\hline & L2-B & 150 & 308 & 2800 & 30 & 1.0 & 399 & 502 & 200 & 49.51 & 33.11 & 3.38 & 3.45 \\
\hline & L3-A & 150 & 315 & 2800 & 30 & 1.4 & 599 & 502 & 200 & 48.34 & 32.33 & 3.33 & 3.43 \\
\hline & L3-B & 150 & 301 & 2800 & 30 & 1.5 & 599 & 502 & 200 & 42.7 & 28.56 & 3.11 & 3.32 \\
\hline & L4-A & 151 & 303 & 2800 & 30 & 2.2 & 799 & 502 & 200 & 52.1 & 34.84 & 3.47 & 3.49 \\
\hline & L4-B & 152 & 306 & 2800 & 30 & 2.2 & 799 & 502 & 200 & 52.1 & 34.84 & 3.47 & 3.49 \\
\hline & L5-A & 149 & 303 & 2800 & 30 & 2.8 & 999 & 502 & 200 & 46.75 & 31.27 & 3.27 & 3.4 \\
\hline & L5-B & 148 & 305 & 2800 & 30 & 2.8 & 999 & 502 & 200 & 46.75 & 31.27 & 2.27 & 3.4 \\
\hline \multirow{9}{*}[60]{} & $\mathrm{B}-\mathrm{N} 2$ & 200 & 250 & 3080 & 26 & 1.2 & 509 & 530 & - & - & 48.61 & 3.69 & 2.46 \\
\hline & B-N3 & 200 & 250 & 3080 & 26 & 1.8 & 763 & 530 & - & - & 48.61 & 3.69 & 2.46 \\
\hline & $\mathrm{B}-\mathrm{N} 4$ & 200 & 250 & 3080 & 26 & 2.4 & 1018 & 530 & - & - & 48.61 & 3.69 & 2.46 \\
\hline & $\mathrm{B}-\mathrm{M} 2$ & 200 & 250 & 3080 & 26 & 1.2 & 509 & 530 & - & - & 78.5 & 5.05 & 3.54 \\
\hline & B-M3 & 200 & 250 & 3080 & 26 & 1.8 & 763 & 530 & - & - & 78.5 & 5.05 & 3.54 \\
\hline & B-M4 & 200 & 250 & 3080 & 26 & 2.4 & 1018 & 530 & - & - & 78.5 & 5.05 & 3.54 \\
\hline & B-H2 & 200 & 250 & 3080 & 26 & 1.2 & 509 & 530 & - & - & 102.4 & 5.59 & 3.84 \\
\hline & B-H3 & 200 & 250 & 3080 & 26 & 1.8 & 763 & 530 & - & - & 102.4 & 5.59 & 3.84 \\
\hline & B-H4 & 200 & 250 & 3080 & 26 & 2.4 & 1018 & 530 & - & - & 102.4 & 5.59 & 3.84 \\
\hline \multirow{3}{*}{ [52] } & L4 & 250 & 400 & 3400 & 35 & 1.3 & 1257 & 435 & 200 & - & 14.3 & 1.432 & 3 \\
\hline & L5 & 250 & 400 & 3400 & 35 & 1.3 & 1257 & 435 & 200 & - & 23.1 & 1.89 & 3.45 \\
\hline & L6 & 250 & 400 & 3400 & 35 & 1.3 & 1257 & 435 & 200 & - & 27.5 & 2.04 & 3.6 \\
\hline
\end{tabular}

Note. Symbol "-" means that the parameter has no relevant data in the literature.

when checked for a strength criterion. According to the analysis results, the strength utilization ratio of reinforcement was considered to meet the requirements of strength and reliability, and hence, the appropriate design yield strength of the $600 \mathrm{MPa}$ grade steel bar was selected as $520 \mathrm{MPa}$.

4.2. Reliable Indicators of Beams under Different Concrete Strength Grades. In the reliability calculation, parameters are divided into deterministic variables and random variables. The deterministic random variables include geometric parameters and design parameters, such as cover thickness and reinforcement ratio. The random variables are load and material parameters, such as concrete strength, reinforcement strength, constant load, and variable load [67-69]. It can be seen from the above analysis that the influence of constant load and variable load on the reliability index of the beam is such that the reliability index of the test beam increased with an increase in the constant load to variable load ratio. When the load ratio reached a certain value, the reliability index of the beam became approximately constant. In order to study the influence of the concrete strength grade on the reliability index, the index was calculated for RC 
TABLE 9: Comparison experimental flexural bearing capacity Mu with Muc calculated by different codes for beams with $500 \mathrm{MPa}$ steel bars.

\begin{tabular}{|c|c|c|c|c|c|c|}
\hline Data sources & $\mathrm{RC}$ beams number & $\begin{array}{c}\text { GB50010 -2010 } \\
M_{u} / M_{u c}\end{array}$ & $\begin{array}{c}\text { SL191 -2008 } \\
M_{u} / M_{u c}\end{array}$ & $\begin{array}{c}\text { DL/T5057-2009 } \\
M_{u} / M_{u c}\end{array}$ & $\begin{array}{c}\text { JTG D62-2012 } \\
M_{u} / M_{u c}\end{array}$ & $\begin{array}{c}\text { ACI 318-2014 } \\
M_{u} / M_{u c}\end{array}$ \\
\hline \multirow{7}{*}{ [54] } & LW-1 & 0.93 & 0.93 & 0.93 & 0.93 & 0.95 \\
\hline & LW-2 & 1.01 & 1.01 & 1.01 & 1.01 & 1.02 \\
\hline & LW-3 & 1.18 & 1.18 & 1.18 & 1.18 & 1.19 \\
\hline & LW-4 & 0.99 & 0.99 & 0.99 & 0.99 & 1.02 \\
\hline & LW-5 & 1.00 & 1.00 & 1.00 & 1.00 & 1.02 \\
\hline & LW-6 & 1.00 & 1.00 & 1.00 & 1.00 & 1.02 \\
\hline & LW-7 & 1.06 & 1.06 & 1.06 & 1.06 & 1.10 \\
\hline \multirow{9}{*}{ [55] } & FB-1 & 1.10 & 1.10 & 1.10 & 1.10 & 1.12 \\
\hline & FB-2 & 0.89 & 0.89 & 0.89 & 0.89 & 0.91 \\
\hline & FB-3 & 1.07 & 1.07 & 1.07 & 1.07 & 1.12 \\
\hline & FB-4 & 1.12 & 1.12 & 1.12 & 1.12 & 1.13 \\
\hline & FB-5 & 1.10 & 1.10 & 1.10 & 1.10 & 1.12 \\
\hline & FB-6 & 1.01 & 1.01 & 1.01 & 1.01 & 1.04 \\
\hline & FB-7 & 1.20 & 1.20 & 1.20 & 1.20 & 1.21 \\
\hline & FB- 8 & 1.09 & 1.09 & 1.09 & 1.09 & 1.11 \\
\hline & FB-9 & 1.18 & 1.18 & 1.18 & 1.18 & 1.22 \\
\hline \multirow{4}{*}[56]{} & B5F1 & 1.17 & 1.17 & 1.17 & 1.17 & 1.18 \\
\hline & B5F2 & 1.22 & 1.22 & 1.22 & 1.22 & 1.25 \\
\hline & B5F3 & 1.09 & 1.09 & 1.09 & 1.09 & 1.10 \\
\hline & B5F4 & 1.20 & 1.20 & 1.20 & 1.20 & 1.22 \\
\hline \multirow{7}{*}{ [57] } & LW-1 & 0.94 & 0.94 & 0.94 & 0.94 & 0.96 \\
\hline & LW-2 & 1.05 & 1.05 & 1.05 & 1.05 & 1.06 \\
\hline & LW-3 & 1.19 & 1.19 & 1.19 & 1.19 & 1.21 \\
\hline & LW-4 & 1.03 & 1.03 & 1.03 & 1.03 & 1.05 \\
\hline & LW-5 & 1.02 & 1.02 & 1.02 & 1.02 & 1.04 \\
\hline & LW-6 & 1.01 & 1.01 & 1.01 & 1.01 & 1.03 \\
\hline & LW-7 & 1.08 & 1.08 & 1.08 & 1.08 & 1.12 \\
\hline \multirow{12}{*}{ [58] } & L1 & 1.01 & 1.01 & 1.01 & 1.01 & 1.04 \\
\hline & L2 & 1.17 & 1.17 & 1.17 & 1.17 & 1.21 \\
\hline & L3 & 1.16 & 1.16 & 1.16 & 1.16 & 1.21 \\
\hline & L4 & 1.13 & 1.13 & 1.13 & 1.13 & 1.20 \\
\hline & LX1-A & 1.01 & 1.01 & 1.01 & 1.01 & 1.03 \\
\hline & LX2-A & 1.11 & 1.11 & 1.11 & 1.11 & 1.15 \\
\hline & LX3-A & 1.18 & 1.18 & 1.18 & 1.18 & 1.23 \\
\hline & LX4-A & 1.17 & 1.17 & 1.17 & 1.17 & 1.23 \\
\hline & LX1-A & 0.97 & 0.97 & 0.97 & 0.97 & 0.99 \\
\hline & LX2-A & 1.09 & 1.09 & 1.09 & 1.09 & 1.13 \\
\hline & LX3-B & 1.19 & 1.19 & 1.19 & 1.19 & 1.24 \\
\hline & LX4-B & 1.15 & 1.15 & 1.15 & 1.15 & 1.22 \\
\hline \multirow{11}{*}{ [59] } & L1-A & 1.18 & 1.18 & 1.18 & 1.18 & 1.19 \\
\hline & L1-B & 1.16 & 1.16 & 1.16 & 1.16 & 1.17 \\
\hline & L1-C & 1.32 & 1.32 & 1.32 & 1.32 & 1.32 \\
\hline & L2-A & 1.07 & 1.07 & 1.07 & 1.07 & 1.09 \\
\hline & L2-B & 1.05 & 1.05 & 1.05 & 1.05 & 1.07 \\
\hline & L3-A & 1.03 & 1.03 & 1.03 & 1.03 & 1.06 \\
\hline & L3-B & 1.09 & 1.09 & 1.09 & 1.09 & 1.12 \\
\hline & L4-A & 0.94 & 0.94 & 0.94 & 0.94 & 0.97 \\
\hline & L4-B & 0.98 & 0.98 & 0.98 & 0.98 & 1.01 \\
\hline & L5-A & 0.93 & 0.93 & 0.93 & 0.93 & 0.97 \\
\hline & L5-B & 0.89 & 0.89 & 0.89 & 0.89 & 0.93 \\
\hline \multirow{9}{*}[60]{} & B-N2 & 1.07 & 1.07 & 1.07 & 1.07 & 1.09 \\
\hline & $\mathrm{B}-\mathrm{N} 3$ & 1.03 & 1.03 & 1.03 & 1.03 & 1.05 \\
\hline & $\mathrm{B}-\mathrm{N} 4$ & 0.99 & 0.99 & 0.99 & 0.99 & 1.01 \\
\hline & B-M2 & 1.04 & 1.04 & 1.04 & 1.04 & 1.05 \\
\hline & B-M3 & 0.98 & 0.98 & 0.98 & 0.98 & 0.99 \\
\hline & B-M4 & 0.97 & 0.97 & 0.97 & 0.97 & 0.99 \\
\hline & B-H2 & 1.01 & 1.01 & 1.01 & 1.01 & 1.02 \\
\hline & B-H3 & 1.00 & 1.00 & 1.00 & 1.00 & 1.01 \\
\hline & B-H4 & 0.99 & 0.99 & 0.99 & 0.99 & 1.00 \\
\hline \multirow{3}{*}{ [52] } & L4 & 0.93 & 0.93 & 0.93 & 0.93 & 0.97 \\
\hline & L5 & 0.86 & 0.86 & 0.86 & 0.86 & 0.89 \\
\hline & L6 & 0.87 & 0.87 & 0.87 & 0.87 & 0.89 \\
\hline$\mu$ & - & 1.06 & 1.06 & 1.06 & 1.06 & 1.09 \\
\hline$\delta$ & - & 0.09 & 0.09 & 0.09 & 0.09 & 0.09 \\
\hline
\end{tabular}


TABle 9: Continued.

\begin{tabular}{|c|c|c|c|c|c|c|}
\hline Data sources & $\mathrm{RC}$ beams number & $\begin{array}{c}\text { EN1992-1-1 } \\
M_{u} / M_{u c}\end{array}$ & $\begin{array}{c}\text { BS5400-4 } \\
M_{u} / M_{u c}\end{array}$ & $\begin{array}{l}\text { AASHEO } \\
M_{u} / M_{u c}\end{array}$ & $\begin{array}{c}\text { EN1991-2 } 2003 \\
M_{u} / M_{u c}\end{array}$ & $\begin{array}{c}\text { CRC PRESS } \\
M_{u} / M_{u c} \\
\end{array}$ \\
\hline \multirow{7}{*}{ [54] } & LW-1 & 0.93 & 1.07 & 0.95 & 0.93 & 0.95 \\
\hline & LW-2 & 1.01 & 1.16 & 1.02 & 1.01 & 1.02 \\
\hline & LW-3 & 1.18 & 1.35 & 1.19 & 1.18 & 1.19 \\
\hline & LW-4 & 0.99 & 1.14 & 1.02 & 0.99 & 1.02 \\
\hline & LW-5 & 1.00 & 1.15 & 1.02 & 1.00 & 1.02 \\
\hline & LW-6 & 1.00 & 1.15 & 1.02 & 1.00 & 1.02 \\
\hline & LW-7 & 1.06 & 1.21 & 1.10 & 1.06 & 1.10 \\
\hline \multirow{9}{*}{ [55] } & FB-1 & 1.10 & 1.27 & 1.12 & 1.10 & 1.12 \\
\hline & FB-2 & 0.89 & 1.02 & 0.91 & 0.89 & 0.91 \\
\hline & FB-3 & 1.07 & 1.23 & 1.12 & 1.07 & 1.12 \\
\hline & FB-4 & 1.12 & 1.28 & 1.13 & 1.12 & 1.13 \\
\hline & FB-5 & 1.10 & 1.27 & 1.12 & 1.10 & 1.12 \\
\hline & FB-6 & 1.01 & 1.16 & 1.04 & 1.01 & 1.04 \\
\hline & FB-7 & 1.20 & 1.38 & 1.21 & 1.20 & 1.21 \\
\hline & FB-8 & 1.09 & 1.25 & 1.11 & 1.09 & 1.11 \\
\hline & FB-9 & 1.18 & 1.36 & 1.22 & 1.18 & 1.22 \\
\hline \multirow{4}{*}[56]{} & B5F1 & 1.17 & 1.37 & 1.18 & 1.17 & 1.18 \\
\hline & $\mathrm{B} 5 \mathrm{~F} 2$ & 1.22 & 1.41 & 1.25 & 1.22 & 1.25 \\
\hline & B5F3 & 1.09 & 1.25 & 1.10 & 1.09 & 1.10 \\
\hline & B5F4 & 1.20 & 1.38 & 1.22 & 1.20 & 1.22 \\
\hline \multirow{7}{*}{ [57] } & LW-1 & 0.94 & 1.08 & 0.96 & 0.94 & 0.96 \\
\hline & LW-2 & 1.05 & 1.20 & 1.06 & 1.05 & 1.06 \\
\hline & LW-3 & 1.19 & 1.37 & 1.21 & 1.19 & 1.21 \\
\hline & LW-4 & 1.03 & 1.18 & 1.05 & 1.03 & 1.05 \\
\hline & LW-5 & 1.02 & 1.17 & 1.04 & 1.02 & 1.04 \\
\hline & LW-6 & 1.01 & 1.16 & 1.03 & 1.01 & 1.03 \\
\hline & LW-7 & 1.08 & 1.24 & 1.12 & 1.08 & 1.12 \\
\hline \multirow{12}{*}{ [58] } & $\mathrm{L} 1$ & 1.01 & 1.16 & 1.04 & 1.01 & 1.04 \\
\hline & L2 & 1.17 & 1.35 & 1.21 & 1.17 & 1.21 \\
\hline & L3 & 1.16 & 1.33 & 1.21 & 1.16 & 1.21 \\
\hline & $\mathrm{L} 4$ & 1.13 & 1.30 & 1.20 & 1.13 & 1.20 \\
\hline & LX1-A & 1.01 & 1.16 & 1.03 & 1.01 & 1.03 \\
\hline & LX2-A & 1.11 & 1.28 & 1.15 & 1.11 & 1.15 \\
\hline & LX3-A & 1.18 & 1.36 & 1.23 & 1.18 & 1.23 \\
\hline & LX4-A & 1.17 & 1.34 & 1.23 & 1.17 & 1.23 \\
\hline & LX1-B & 0.97 & 1.12 & 0.99 & 0.97 & 0.99 \\
\hline & LX2-B & 1.09 & 1.25 & 1.13 & 1.09 & 1.13 \\
\hline & LX3-B & 1.19 & 1.37 & 1.24 & 1.19 & 1.24 \\
\hline & LX4-B & 1.15 & 1.33 & 1.22 & 1.15 & 1.22 \\
\hline \multirow{11}{*}{ [59] } & L1-A & 1.18 & 1.36 & 1.19 & 1.18 & 1.19 \\
\hline & L1-B & 1.16 & 1.34 & 1.17 & 1.16 & 1.17 \\
\hline & L1-C & 1.32 & 1.51 & 1.32 & 1.32 & 1.32 \\
\hline & L2-A & 1.07 & 1.23 & 1.09 & 1.07 & 1.09 \\
\hline & L2-B & 1.05 & 1.21 & 1.07 & 1.05 & 1.07 \\
\hline & L3-A & 1.03 & 1.19 & 1.06 & 1.03 & 1.06 \\
\hline & L3-B & 1.09 & 1.25 & 1.12 & 1.09 & 1.12 \\
\hline & L4-A & 0.94 & 1.03 & 0.97 & 0.94 & 0.97 \\
\hline & L4-B & 0.98 & 1.12 & 1.01 & 0.98 & 1.01 \\
\hline & L5-A & 0.93 & 1.07 & 0.97 & 0.93 & 0.97 \\
\hline & L5-B & 0.89 & 1.02 & 0.93 & 0.89 & 0.93 \\
\hline \multirow{9}{*}{ [60] } & B-N2 & 1.07 & 1.23 & 1.09 & 1.07 & 1.09 \\
\hline & B-N3 & 1.03 & 1.18 & 1.05 & 1.03 & 1.05 \\
\hline & B-N4 & 0.99 & 1.13 & 1.01 & 0.99 & 1.01 \\
\hline & $\mathrm{B}-\mathrm{M} 2$ & 1.04 & 1.20 & 1.05 & 1.04 & 1.05 \\
\hline & B-M3 & 0.98 & 1.12 & 0.99 & 0.98 & 0.99 \\
\hline & B-M4 & 0.97 & 1.12 & 0.99 & 0.97 & 0.99 \\
\hline & B-H2 & 1.01 & 1.16 & 1.02 & 1.01 & 1.02 \\
\hline & B-H3 & 1.00 & 1.15 & 1.01 & 1.00 & 1.01 \\
\hline & B-H4 & 0.99 & 1.14 & 1.00 & 0.99 & 1.00 \\
\hline \multirow{3}{*}{ [52] } & $\mathrm{L} 4$ & 0.93 & 1.07 & 0.73 & 0.93 & 0.87 \\
\hline & L5 & 0.86 & 0.99 & 0.75 & 0.99 & 0.83 \\
\hline & L6 & 0.87 & 1.00 & 0.78 & 1.03 & 0.84 \\
\hline$\mu$ & - & 1.06 & 1.22 & 1.01 & 1.06 & 1.08 \\
\hline$\delta$ & - & 0.09 & 0.09 & 0.11 & 0.09 & 0.10 \\
\hline
\end{tabular}

Note. $M_{\mathrm{u}}$ in the table is the measured ultimate flexural bearing capacity and $M_{\mathrm{uc}}$ is the calculated value of ultimate flexural bearing capacity obtained by taking the measured yield strength of reinforcement from the current code formulas. 


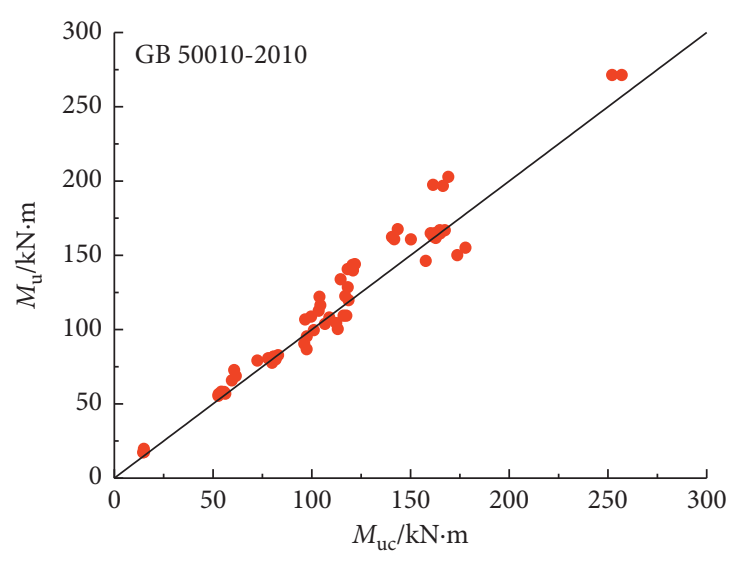

(a)

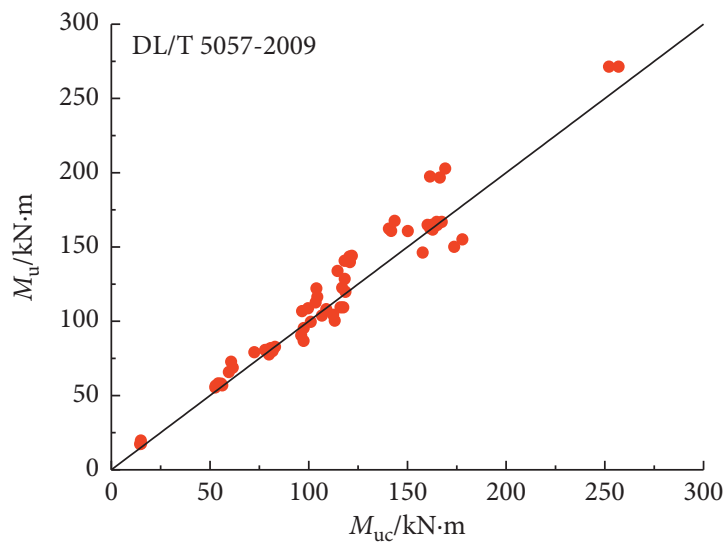

(c)

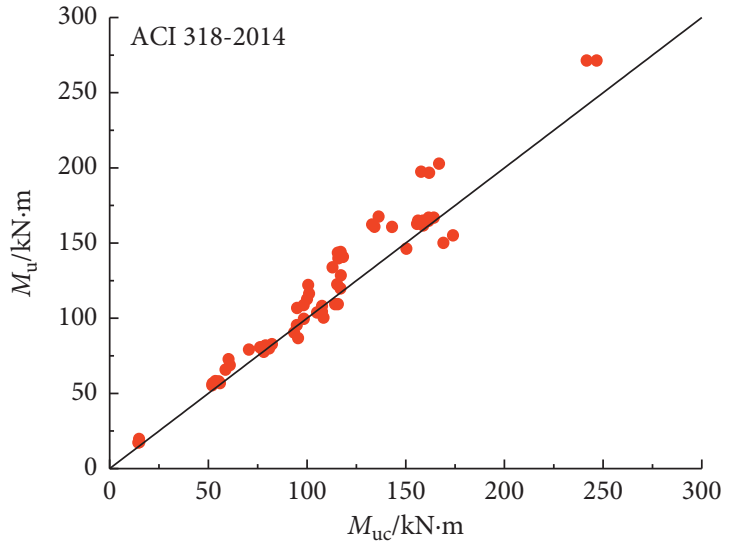

(e)

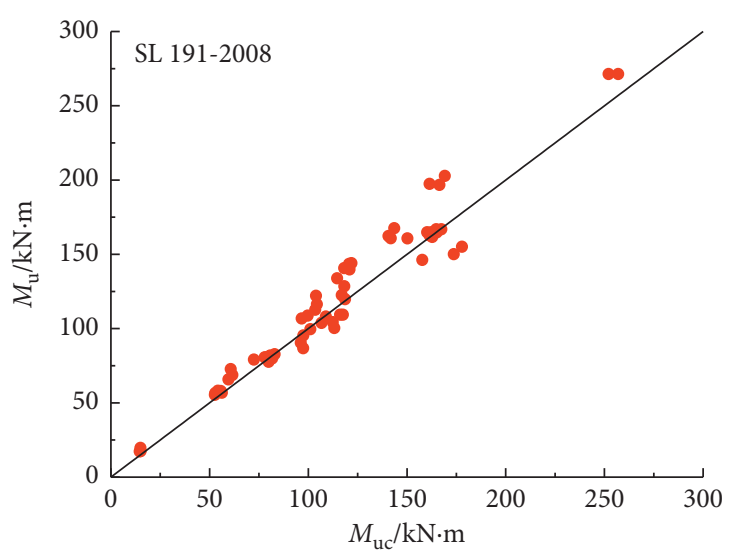

(b)

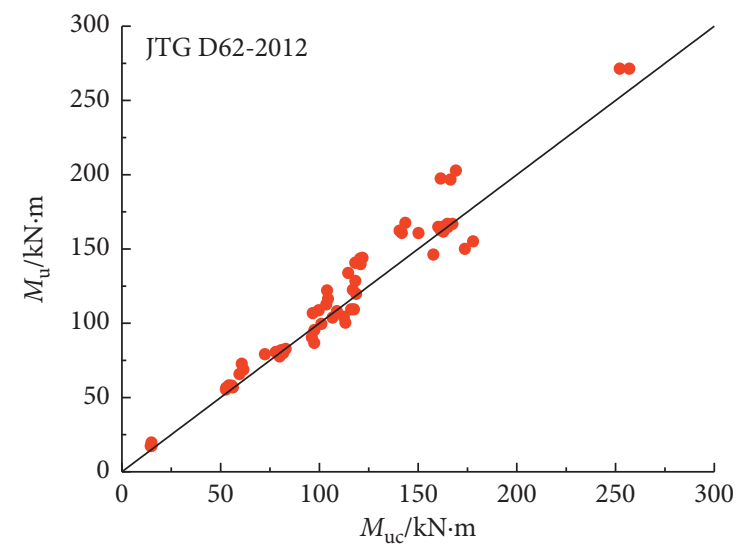

(d)

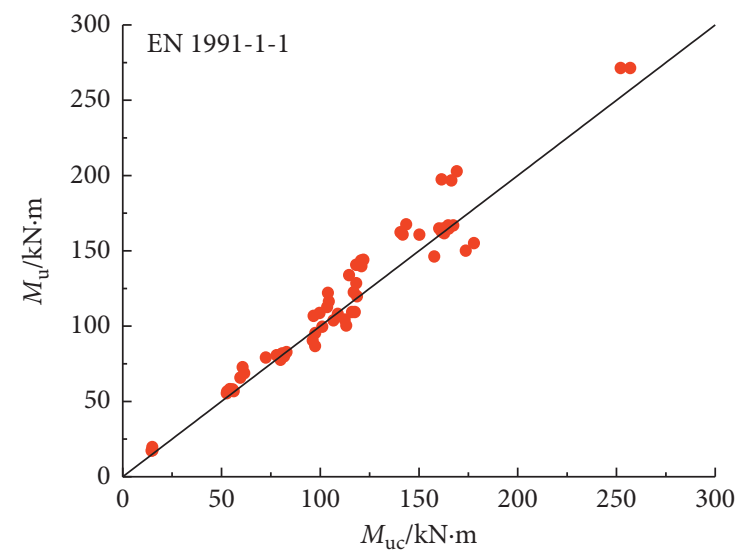

(f)

Figure 7: Continued. 


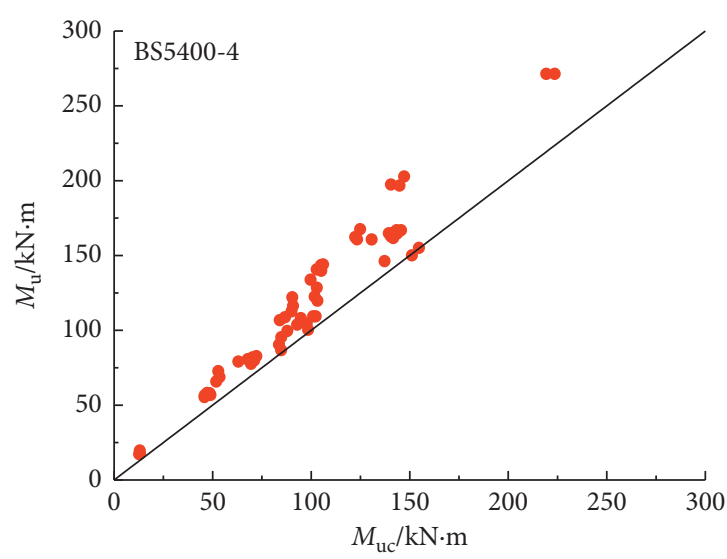

(g)

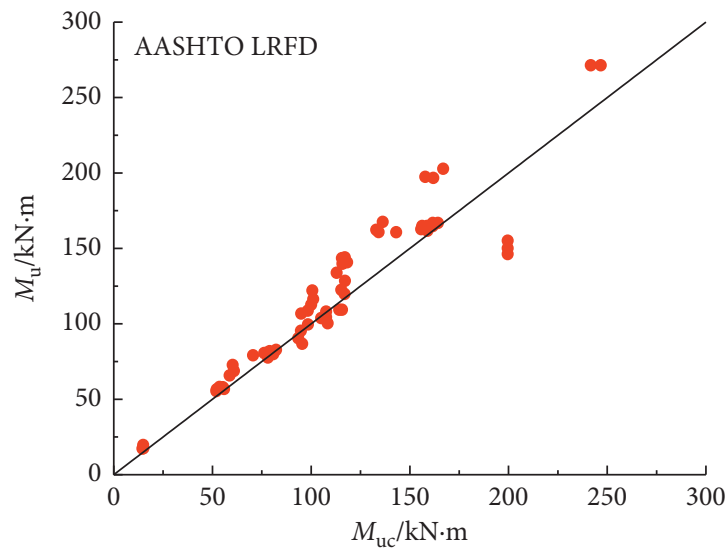

(i)

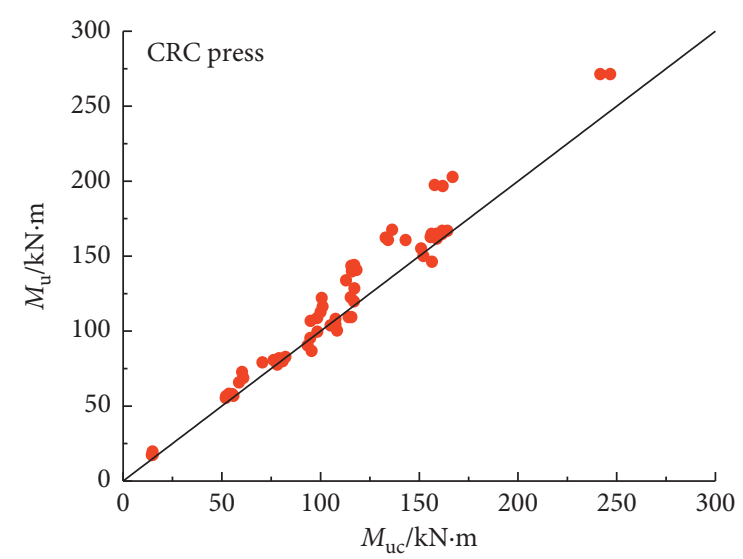

(h)

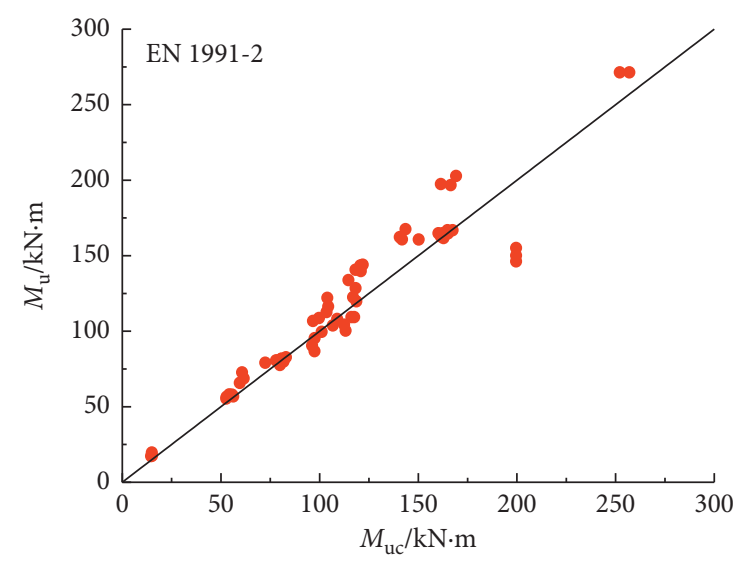

(j)

FiguRE 7: Comparison of experimental flexural bearing capacity $M_{\mathrm{u}}$ with $M_{\mathrm{uc}}$ calculated by different codes for beams with $500 \mathrm{MPa}$ steel bars.

beams reinforced with $600 \mathrm{MPa}$ grade steel and having the concrete grade of $\mathrm{C} 40, \mathrm{C} 50$, and C60. The reliability analysis of the flexural bearing capacity of RC beam was calculated by considering the design yield strength of the steel bar as $520 \mathrm{MPa}$.

As shown in Figures 11 and 12, the trend of change in $\rho-\beta$ curve corresponding to different concrete strength grades was basically the same for the two reinforcement ratios of $600 \mathrm{MPa}$ grade steel. Generally speaking, the reliability index of the beam increased with an increase in the strength of concrete, but the increase was not large.

The curve of the minimum value of the reliability index of the beam with different concrete strength grades is shown in Figure 13. The trend of change in the minimum value of the reliability index of the beam under different reinforcement ratios was basically the same. With an improvement in the concrete strength grade, the minimum value of the reliability index increased; when the reinforcement ratio is small, the minimum value of the reliability index of the beam is larger.

Table 14 shows the statistical parameters of the minimum reliability index corresponding to different concrete strength grades of the test beams. The average value of the minimum reliability index of the test beams with a reinforcement ratio of 0.005 was 3.172 for each concrete strength grade. The average value of the minimum reliability index corresponded to the failure probability of $7.57 \times 10^{-4}$. The average value of the minimum reliability index for different concrete grades with a reinforcement ratio of 0.008 was 3.148 , and the average value of the minimum reliability index corresponded to the failure probability of $8.23 \times 10^{-4}$. The overall average minimum reliability index of the test beam (irrespective of the reinforcement ratio) was 3.160, and the corresponding failure probability was $7.89 \times 10^{-4}$. These values are close to the code specified values. The coefficient of variation of the minimum reliability index corresponding to different concrete strength grades was negligibly small, indicating that the minimum reliability index was less affected by the concrete strength grade and had good stability. The analysis of the minimum reliability index of the beams with different concrete strength grades further verified that the design yield strength of the $600 \mathrm{MPa}$ grade steel bar should be taken as $520 \mathrm{MPa}$ to meet the reliability requirements. 
TABLE 10: Details of beams with $600 \mathrm{MPa}$ steel bars.

\begin{tabular}{|c|c|c|c|c|c|c|c|c|c|c|c|c|c|}
\hline \multirow{2}{*}{$\begin{array}{l}\text { Data } \\
\text { sources }\end{array}$} & \multirow{2}{*}{$\begin{array}{l}\text { RC beam } \\
\text { number }\end{array}$} & \multirow{2}{*}{$b / \mathrm{mm}$} & \multirow{2}{*}{$h / \mathrm{mm}$} & \multirow{2}{*}{$l_{0} / \mathrm{mm}$} & \multirow{2}{*}{$c / \mathrm{mm}$} & \multirow{2}{*}{$\rho / 100 \%$} & \multicolumn{3}{|c|}{ Reinforcement } & \multicolumn{4}{|c|}{ Concrete } \\
\hline & & & & & & & $A_{\mathrm{s}} / \mathrm{mm}^{2}$ & $\mathrm{fy} / \mathrm{MPa}$ & Es/GPa & $F c u / M P a$ & $F \mathrm{ck} / \mathrm{MPa}$ & $\mathrm{fts} / \mathrm{MPa}$ & $E \mathrm{c} \times 104 / \mathrm{MPa}$ \\
\hline \multirow{6}{*}{ [39] } & L-5 & 200 & 400 & 3200 & 30 & 1.3 & 982 & 622 & - & 54.67 & 35.3 & 2.80 & 3.52 \\
\hline & L-7 & 200 & 400 & 3200 & 30 & 1.3 & 982 & 622 & - & 54.67 & 35.3 & 2.80 & 3.52 \\
\hline & L-8 & 200 & 400 & 3200 & 30 & 1.0 & 763 & 654 & - & 54.67 & 35.3 & 2.80 & 3.52 \\
\hline & L-9 & 200 & 400 & 3200 & 30 & 0.7 & 509 & 654 & - & 54.67 & 35.3 & 2.80 & 3.52 \\
\hline & L-10 & 200 & 400 & 3200 & 30 & 1.0 & 763 & 654 & - & 67.42 & 45.49 & 3.68 & 3.68 \\
\hline & $\mathrm{L}-11$ & 200 & 400 & 3200 & 30 & 0.7 & 509 & 654 & - & 67.42 & 45.49 & 3.68 & 3.68 \\
\hline \multirow{6}{*}{ [61] } & LW-1 & 200 & 400 & 3200 & 30 & - & 509 & 654 & - & 54.27 & 35.11 & 3.02 & - \\
\hline & LW-2 & 200 & 400 & 3200 & 30 & - & 509 & 654 & - & 67.42 & 43.27 & 3.09 & - \\
\hline & LW-3 & 200 & 400 & 3200 & 30 & - & 763 & 654 & - & 54.27 & 35.11 & 3.02 & - \\
\hline & LW-4 & 200 & 400 & 3200 & 30 & - & 763 & 654 & - & 67.42 & 43.27 & 3.09 & - \\
\hline & LW-5 & 200 & 400 & 3200 & 30 & - & 982 & 622 & - & 54.27 & 35.11 & 3.02 & - \\
\hline & LW-6 & 200 & 400 & 3200 & 30 & - & 982 & 622 & - & 67.42 & 43.27 & 3.09 & - \\
\hline \multirow{4}{*}{ [53] } & LW1 & 200 & 400 & 3000 & 25 & 0.8 & 603 & 645 & - & 19.5 & 19.5 & 2.22 & - \\
\hline & LW2 & 200 & 400 & 3000 & 25 & 0.8 & 603 & 645 & - & 31.2 & 31.2 & 2.85 & - \\
\hline & LW3 & 200 & 400 & 300 & 25 & 1.4 & 982 & 610 & - & 19.5 & 19.5 & 2.22 & - \\
\hline & LW4 & 200 & 400 & 3000 & 25 & 1.4 & 982 & 610 & - & 31.5 & 31.2 & 2.85 & - \\
\hline \multirow{3}{*}{ [52] } & L-1 & 250 & 400 & 3400 & 35 & 1.1 & 1140 & 500 & 200 & - & 14.3 & 1.43 & 3.0 \\
\hline & L-2 & 250 & 400 & 3400 & 35 & 1.1 & 1140 & 500 & 200 & - & 23.1 & 1.89 & 3.45 \\
\hline & L-3 & 250 & 400 & 3400 & 35 & 1.1 & 1140 & 500 & 200 & - & 27.5 & 2.04 & 3.6 \\
\hline
\end{tabular}

Note. Symbol "-" means that the parameter has no relevant data in the literature.

TABLE 11: Comparison of experimental flexural bearing capacity $M_{\mathrm{u}}$ with $M_{\mathrm{uc}}$ calculated by different codes for beams with $600 \mathrm{MPa}$ steel bars.

\begin{tabular}{|c|c|c|c|c|c|c|}
\hline Data sources & $\mathrm{RC}$ beam number & $\begin{array}{c}\text { GB50010-2010 } \\
M_{\mathrm{u}} / M_{\mathrm{uc}}\end{array}$ & $\begin{array}{c}\text { SL191 }-2008 \\
M_{\mathrm{u}} / M_{\mathrm{uc}}\end{array}$ & $\begin{array}{c}\mathrm{DL} / \mathrm{T} 5057-2009 \\
M_{\mathrm{u}} / M_{\mathrm{uc}}\end{array}$ & $\begin{array}{c}\text { JTGD62-2012 } \\
M_{\mathrm{u}} / M_{\mathrm{uc}}\end{array}$ & $\begin{array}{c}\mathrm{ACI} 318-2014 \\
M_{\mathrm{u}} / M_{\mathrm{uc}} \\
\end{array}$ \\
\hline \multirow{16}{*}{ Test } & $600-\mathrm{C} 30-1-1$ & 1.16 & 1.16 & 1.16 & 1.16 & 1.18 \\
\hline & $600-C 30-1-2$ & 1.15 & 1.15 & 1.15 & 1.15 & 1.17 \\
\hline & $600-\mathrm{C} 30-2-1$ & 1.20 & 1.20 & 1.20 & 1.20 & 1.22 \\
\hline & $600-C 30-2-2$ & 1.19 & 1.19 & 1.19 & 1.19 & 1.20 \\
\hline & $600-C 40-1-1$ & 1.06 & 1.06 & 1.06 & 1.06 & 1.08 \\
\hline & $600-C 40-1-2$ & 1.04 & 1.04 & 1.04 & 1.04 & 1.06 \\
\hline & $600-C 40-2-1$ & 1.10 & 1.10 & 1.10 & 1.10 & 1.11 \\
\hline & $600-C 40-2-2$ & 1.25 & 1.25 & 1.25 & 1.25 & 1.27 \\
\hline & $600-C 50-1-1$ & 1.04 & 1.04 & 1.04 & 1.04 & 1.06 \\
\hline & $600-C 50-1-2$ & 1.10 & 1.10 & 1.10 & 1.10 & 1.12 \\
\hline & $600-C 50-2-1$ & 1.16 & 1.16 & 1.16 & 1.16 & 1.17 \\
\hline & $600-C 50-2-2$ & 1.19 & 1.19 & 1.19 & 1.19 & 1.20 \\
\hline & $600-\mathrm{C} 60-1-1$ & 1.08 & 1.08 & 1.08 & 1.08 & 1.09 \\
\hline & $600-C 60-1-2$ & 1.07 & 1.07 & 1.07 & 1.07 & 1.08 \\
\hline & $600-C 60-2-1$ & 1.20 & 1.20 & 1.20 & 1.20 & 1.20 \\
\hline & $600-C 60-2-2$ & 1.20 & 1.20 & 1.20 & 1.20 & 1.20 \\
\hline \multirow{6}{*}{ [39] } & L-5 & 1.16 & 1.16 & 1.16 & 1.16 & 1.29 \\
\hline & L-7 & 1.11 & 1.11 & 1.11 & 1.11 & 1.24 \\
\hline & L-8 & 1.14 & 1.14 & 1.14 & 1.14 & 1.24 \\
\hline & L-9 & 1.13 & 1.13 & 1.13 & 1.13 & 1.19 \\
\hline & L-10 & 1.13 & 1.13 & 1.13 & 1.13 & 1.19 \\
\hline & L-11 & 1.11 & 1.11 & 1.11 & 1.11 & 1.15 \\
\hline \multirow{6}{*}{ [61] } & LW-1 & 1.13 & 1.13 & 1.13 & 1.13 & 1.14 \\
\hline & LW-2 & 1.14 & 1.14 & 1.14 & 1.14 & 1.15 \\
\hline & LW-3 & 1.14 & 1.14 & 1.14 & 1.14 & 1.16 \\
\hline & LW-4 & 1.13 & 1.13 & 1.13 & 1.13 & 1.15 \\
\hline & LW-5 & 1.12 & 1.12 & 1.12 & 1.12 & 1.14 \\
\hline & LW-6 & 1.13 & 1.13 & 1.13 & 1.13 & 1.15 \\
\hline
\end{tabular}


TABle 11: Continued.

\begin{tabular}{|c|c|c|c|c|c|c|}
\hline Data sources & $\mathrm{RC}$ beam number & $\begin{array}{c}\text { GB50010-2010 } \\
M_{\mathrm{u}} / M_{\mathrm{uc}} \\
\end{array}$ & $\begin{array}{c}\text { SL191 }-2008 \\
M_{\mathrm{u}} / M_{\mathrm{uc}} \\
\end{array}$ & $\begin{array}{c}\mathrm{DL} / \mathrm{T} 5057-2009 \\
M_{\mathrm{u}} / M_{\mathrm{uc}} \\
\end{array}$ & $\begin{array}{c}\text { JTGD62-2012 } \\
M_{\mathrm{u}} / M_{\mathrm{uc}} \\
\end{array}$ & $\begin{array}{c}\mathrm{ACI} 318-2014 \\
M_{\mathrm{u}} / M_{\mathrm{uc}} \\
\end{array}$ \\
\hline \multirow{4}{*}[53]{} & LW1 & 1.13 & 1.13 & 1.13 & 1.13 & 1.16 \\
\hline & LW2 & 1.05 & 1.05 & 1.05 & 1.05 & 1.07 \\
\hline & LW3 & 1.08 & 1.08 & 1.08 & 1.08 & 1.13 \\
\hline & LW4 & 1.06 & 1.06 & 1.06 & 1.06 & 1.09 \\
\hline \multirow{3}{*}[52]{} & L-1 & 0.92 & 0.92 & 0.92 & 0.92 & 0.97 \\
\hline & $\mathrm{L}-2$ & 0.90 & 0.90 & 0.90 & 0.90 & 0.93 \\
\hline & $\mathrm{L}-3$ & 0.89 & 0.89 & 0.89 & 0.89 & 0.91 \\
\hline$\mu$ & - & 1.11 & 1.11 & 1.11 & 1.11 & 1.14 \\
\hline$\delta$ & - & 0.07 & 0.07 & 0.07 & 0.07 & 0.08 \\
\hline \multirow{2}{*}{ Data sources } & \multirow{2}{*}{ RC beam number } & EN1992-1-1 & BS5400-4 & AASHEO & EN1991-2 2003 & CRC PRESS \\
\hline & & $M_{\mathrm{u}} / M_{\mathrm{uc}}$ & $M_{\mathrm{u}} / M_{\mathrm{uc}}$ & $M_{\mathrm{u}} / M_{\mathrm{uc}}$ & $M_{\mathrm{u}} / M_{\mathrm{uc}}$ & $M_{\mathrm{u}} / M_{\mathrm{uc}}$ \\
\hline \multirow{16}{*}{ Test } & $600-C 30-1-1$ & 1.14 & 1.33 & 1.18 & 1.10 & 1.18 \\
\hline & $600-C 30-1-2$ & 1.13 & 1.32 & 1.17 & 1.09 & 1.17 \\
\hline & $600-C 30-2-1$ & 1.19 & 1.38 & 1.22 & 1.17 & 1.22 \\
\hline & $600-C 30-2-2$ & 1.20 & 1.37 & 1.20 & 1.18 & 1.20 \\
\hline & $600-C 40-1-1$ & 1.06 & 1.22 & 1.08 & 1.04 & 1.08 \\
\hline & $600-C 40-1-2$ & 1.04 & 1.20 & 1.06 & 1.02 & 1.06 \\
\hline & $600-C 40-2-1$ & 1.10 & 1.27 & 1.11 & 1.09 & 1.11 \\
\hline & $600-C 40-2-2$ & 1.25 & 1.44 & 1.27 & 1.24 & 1.27 \\
\hline & $600-\mathrm{C} 50-1-1$ & 1.04 & 1.19 & 1.06 & 1.01 & 1.06 \\
\hline & $600-C 50-1-2$ & 1.10 & 1.27 & 1.12 & 1.07 & 1.12 \\
\hline & $600-C 50-2-1$ & 1.16 & 1.34 & 1.17 & 1.14 & 1.17 \\
\hline & $600-C 50-2-2$ & 1.19 & 1.37 & 1.20 & 1.17 & 1.20 \\
\hline & $600-\mathrm{C} 60-1-1$ & 1.08 & 1.24 & 1.09 & 1.08 & 1.09 \\
\hline & $600-C 60-1-2$ & 1.07 & 1.23 & 1.08 & 1.07 & 1.08 \\
\hline & $600-\mathrm{C} 60-2-1$ & 1.20 & 1.37 & 1.20 & 1.20 & 1.20 \\
\hline & $600-\mathrm{C} 60-2-2$ & 1.20 & 1.37 & 1.20 & 1.20 & 1.20 \\
\hline \multirow{6}{*}[39]{} & L-5 & 1.24 & 1.33 & 1.19 & 1.16 & 1.19 \\
\hline & $\mathrm{L}-7$ & 1.20 & 1.28 & 1.14 & 1.11 & 1.14 \\
\hline & L-8 & 1.20 & 1.31 & 1.16 & 1.14 & 1.16 \\
\hline & L-9 & 1.17 & 1.29 & 1.14 & 1.13 & 1.14 \\
\hline & $\mathrm{L}-10$ & 1.17 & 1.30 & 1.14 & 1.13 & 1.14 \\
\hline & $\mathrm{L}-11$ & 1.13 & 1.28 & 1.12 & 1.11 & 1.12 \\
\hline \multirow{6}{*}[61]{} & LW-1 & 1.13 & 1.30 & 1.14 & 1.13 & 1.14 \\
\hline & LW-2 & 1.14 & 1.31 & 1.15 & 1.14 & 1.15 \\
\hline & LW-3 & 1.14 & 1.31 & 1.16 & 1.14 & 1.16 \\
\hline & LW-4 & 1.13 & 1.30 & 1.15 & 1.13 & 1.15 \\
\hline & LW-5 & 1.12 & 1.28 & 1.14 & 1.12 & 1.14 \\
\hline & LW-6 & 1.13 & 1.30 & 1.15 & 1.13 & 1.15 \\
\hline \multirow{4}{*}{ [53] } & LW1 & 1.13 & 1.30 & 1.16 & 1.13 & 1.16 \\
\hline & LW2 & 1.05 & 1.20 & 1.07 & 1.05 & 1.07 \\
\hline & LW3 & 1.08 & 1.24 & 1.13 & 1.08 & 1.13 \\
\hline & LW4 & 1.06 & 1.22 & 1.09 & 1.06 & 1.09 \\
\hline \multirow{3}{*}{ [52] } & L-1 & 0.92 & 1.06 & 0.97 & 0.92 & 0.97 \\
\hline & L-2 & 0.90 & 1.04 & 0.93 & 0.90 & 0.93 \\
\hline & L-3 & 0.89 & 1.02 & 0.91 & 0.89 & 0.91 \\
\hline$\mu$ & - & 1.12 & 1.27 & 1.13 & 1.10 & 1.13 \\
\hline$\delta$ & - & 0.08 & 0.07 & 0.07 & 0.07 & 0.07 \\
\hline
\end{tabular}

Note. $M_{\mathrm{u}}$ in the table is the measured ultimate flexural bearing capacity and $M_{\mathrm{uc}}$ is the calculated value of ultimate flexural bearing capacity obtained by taking the measured yield strength of reinforcement from the current code formulas. 


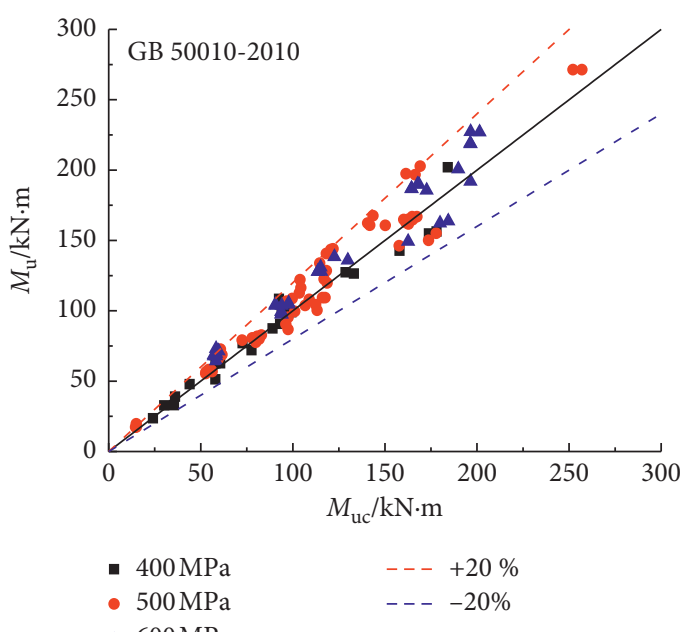

(a)

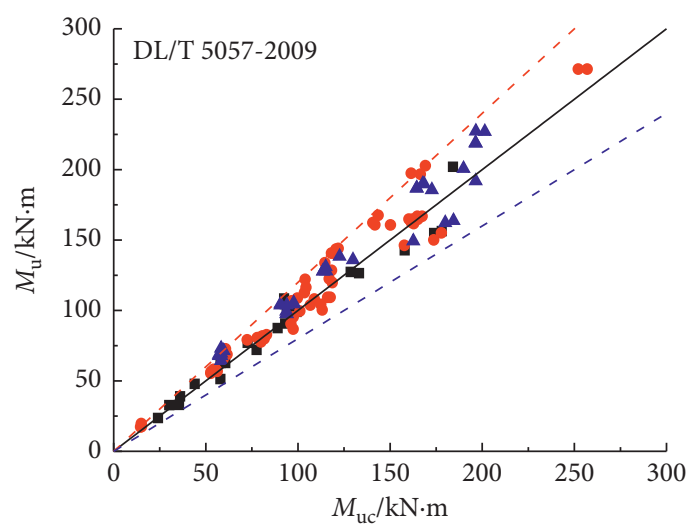

- $400 \mathrm{MPa}$

- $500 \mathrm{MPa}$

- $600 \mathrm{MPa}$

(c)

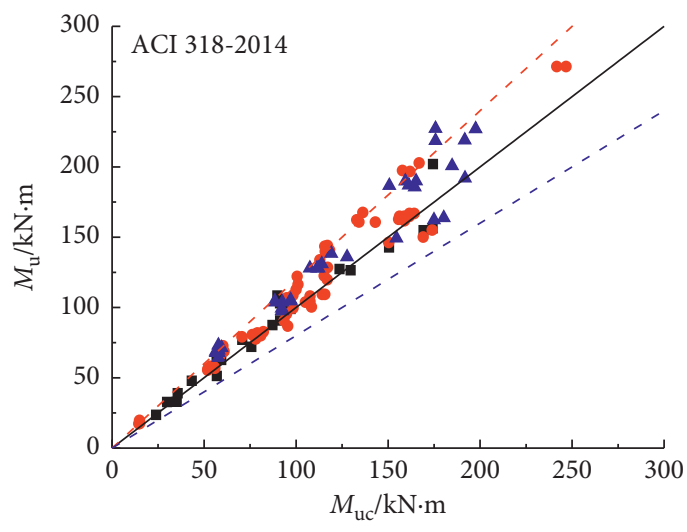

- $400 \mathrm{MPa}$

- $500 \mathrm{MPa}$

- $600 \mathrm{MPa}$

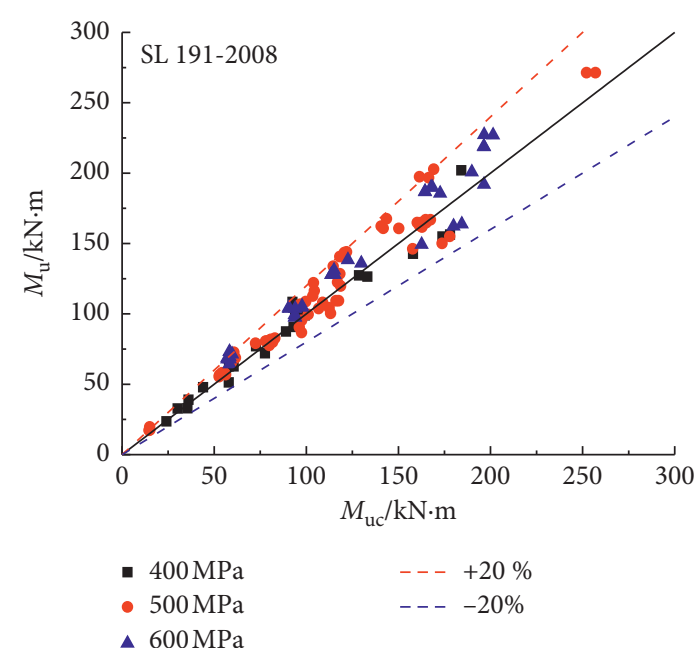

(b)

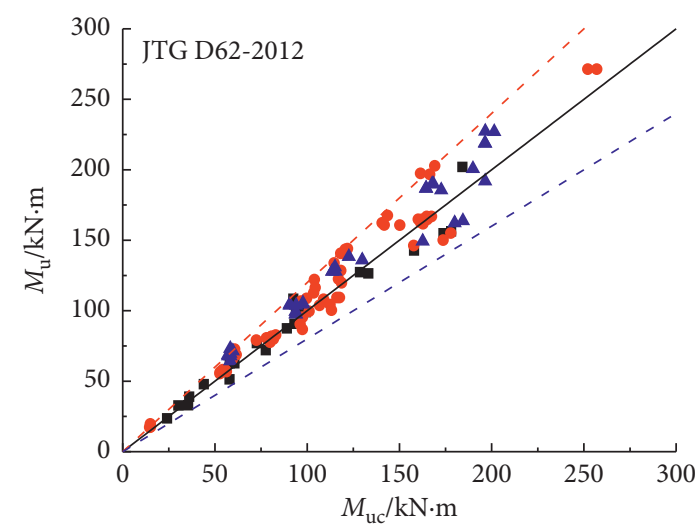

- $400 \mathrm{MPa}$

- $500 \mathrm{MPa}$

- $600 \mathrm{MPa}$

- - $+20 \%$

- - - $20 \%$

(d)

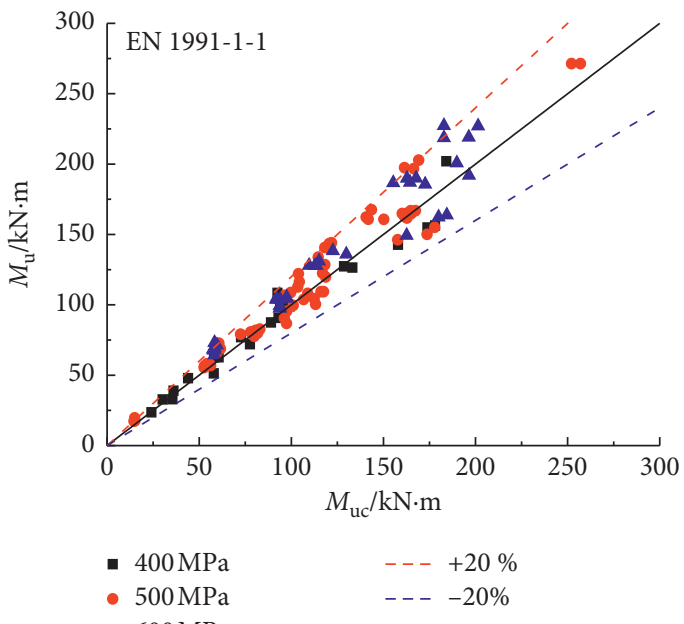

- $600 \mathrm{MPa}$

(e)

Figure 8: Continued. 


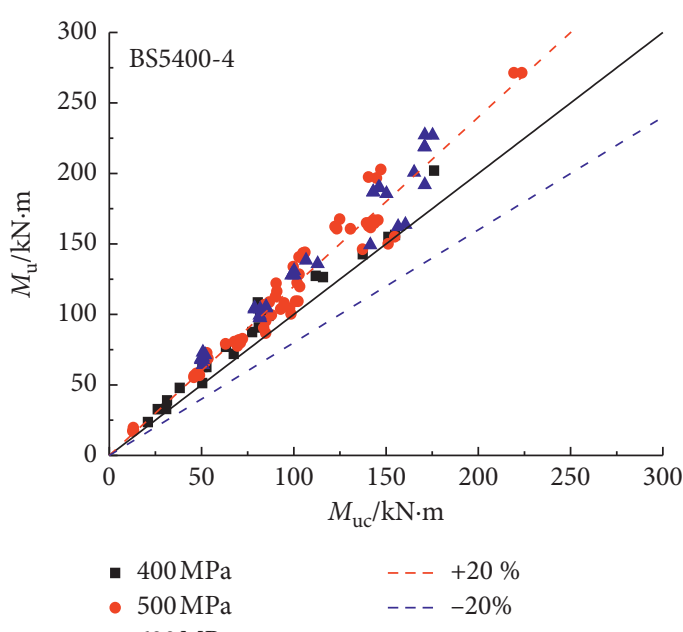

(g)

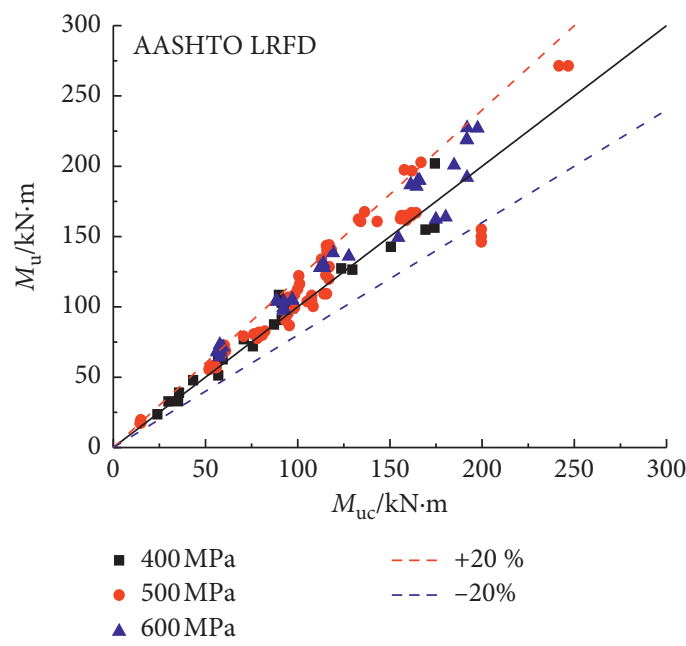

(i)

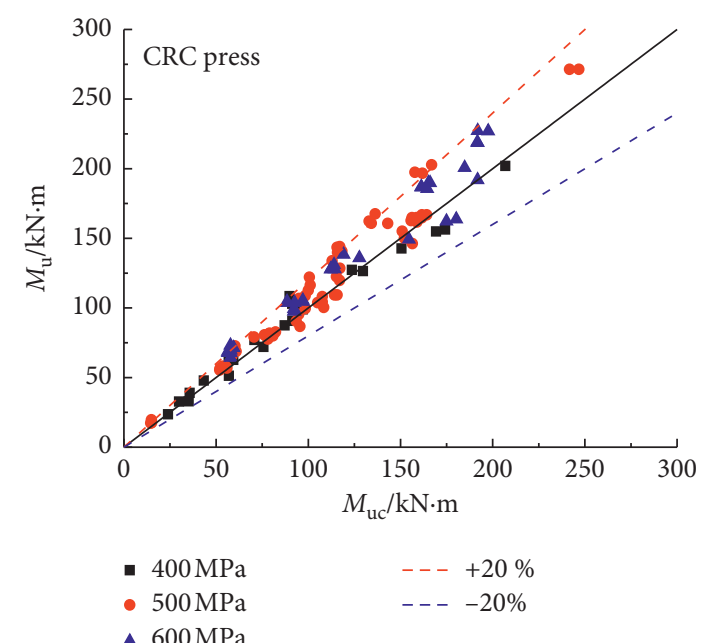

(h)

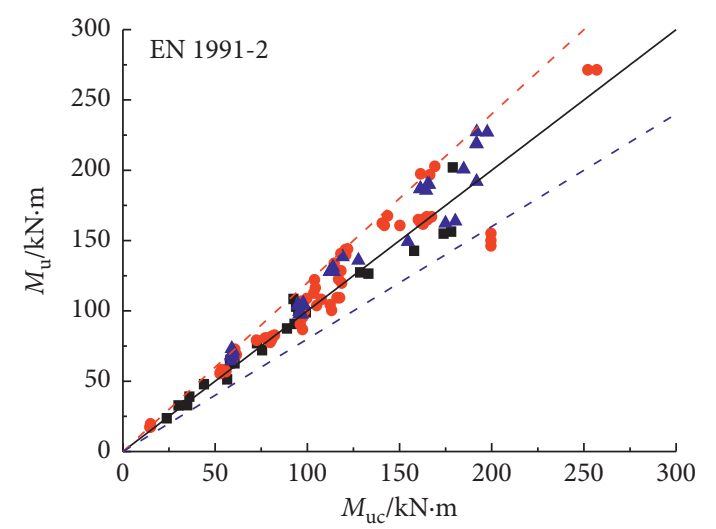

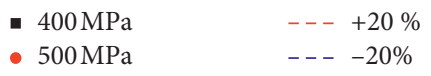

\ $600 \mathrm{MPa}$

(j)

FIGURE 8: Comparison of experimental flexural bearing capacity $M_{\mathrm{u}}$ with $M_{\mathrm{uc}}$ calculated by different codes for beams with $600 \mathrm{MPa}$ steel bars.

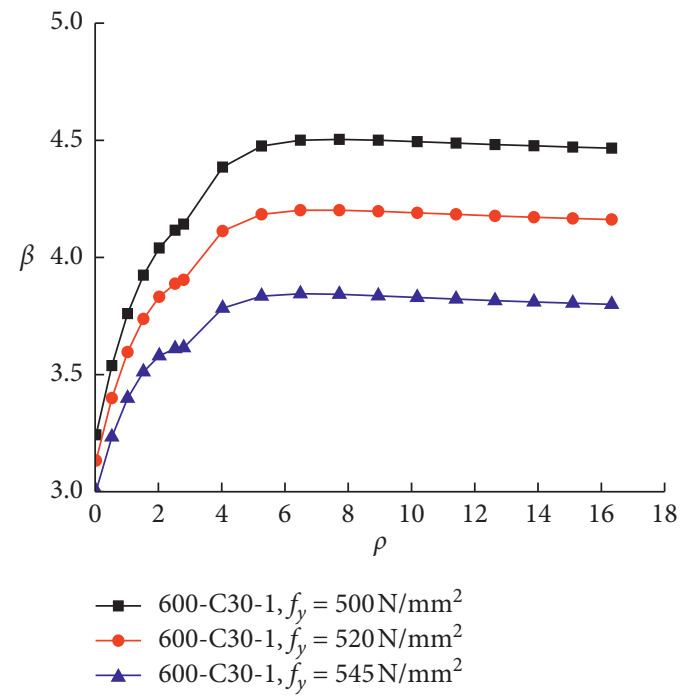

(a)

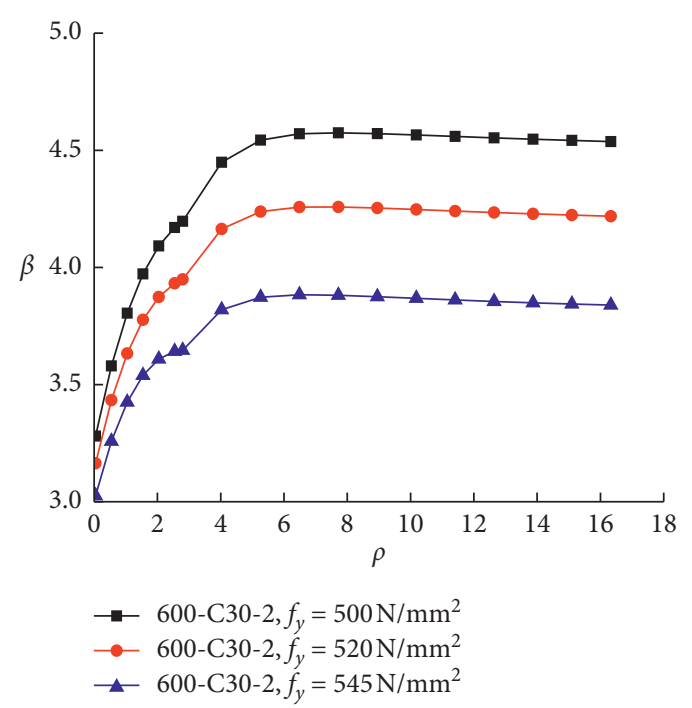

(b)

FIgUre 9: Continued. 


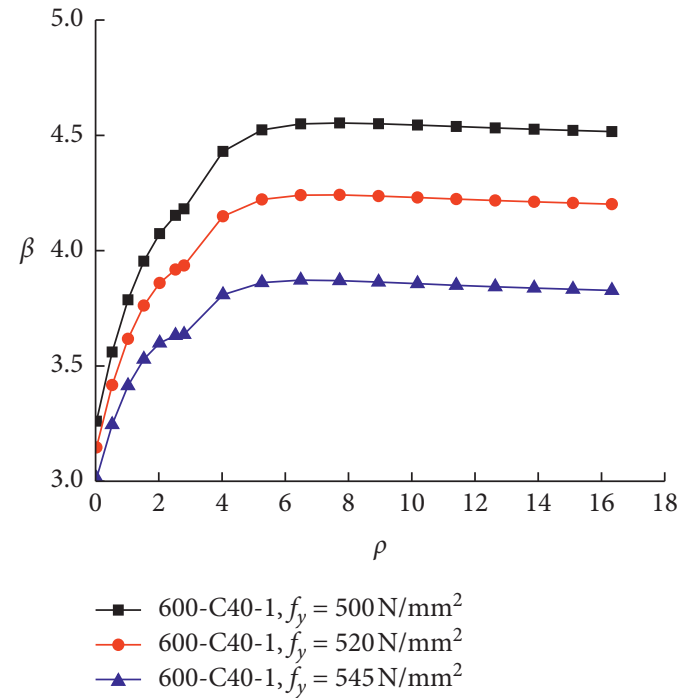

(c)

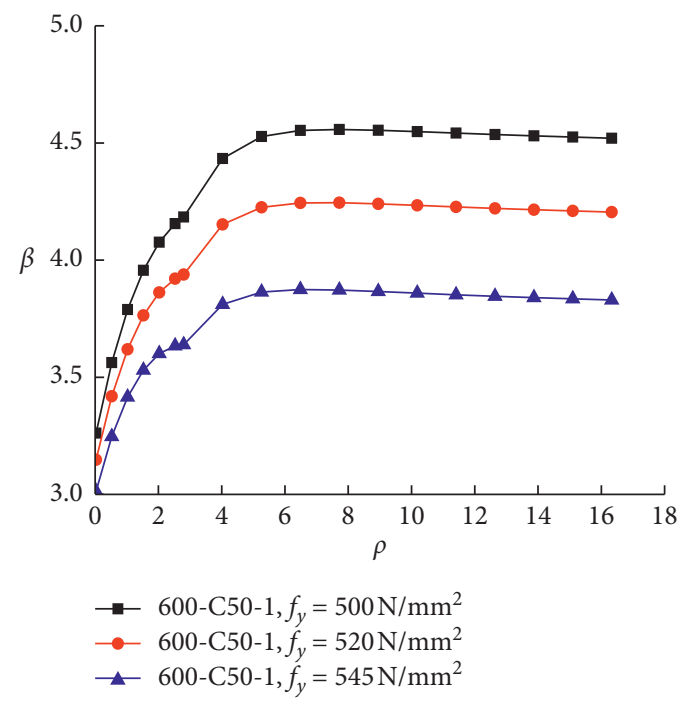

(e)

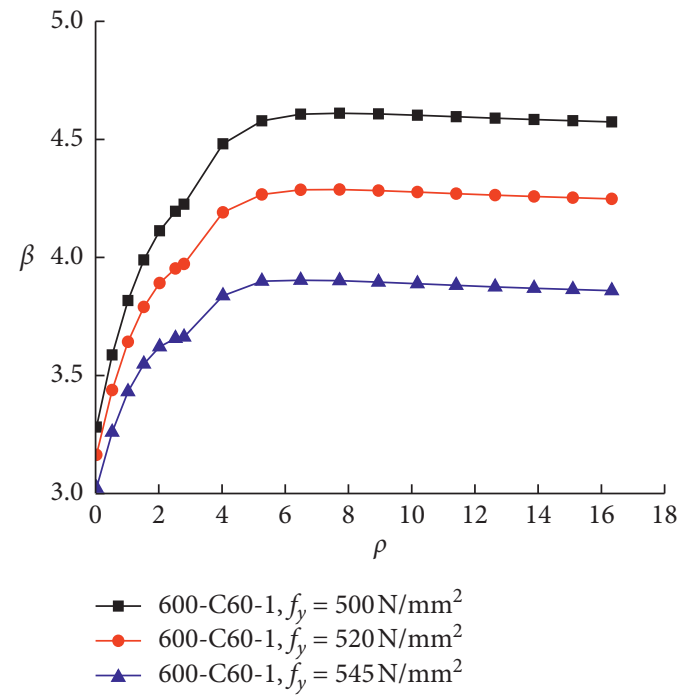

(g)

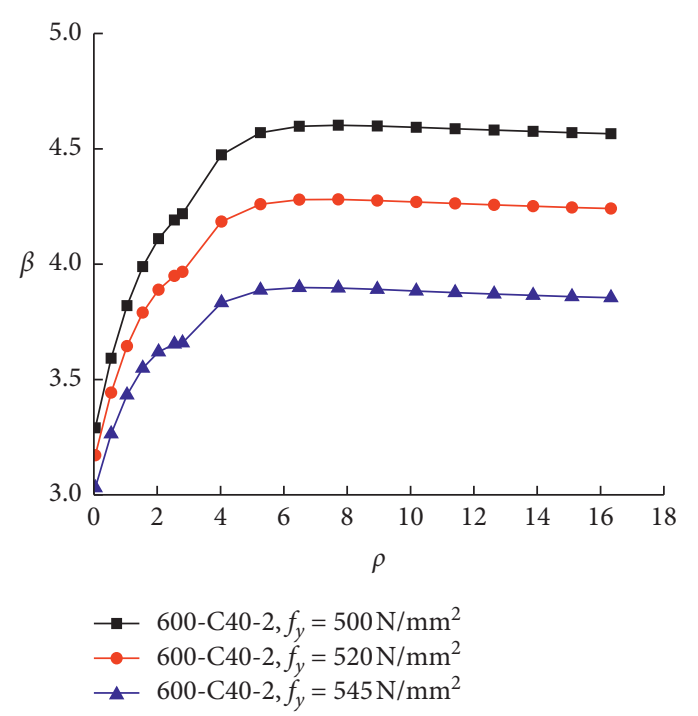

(d)

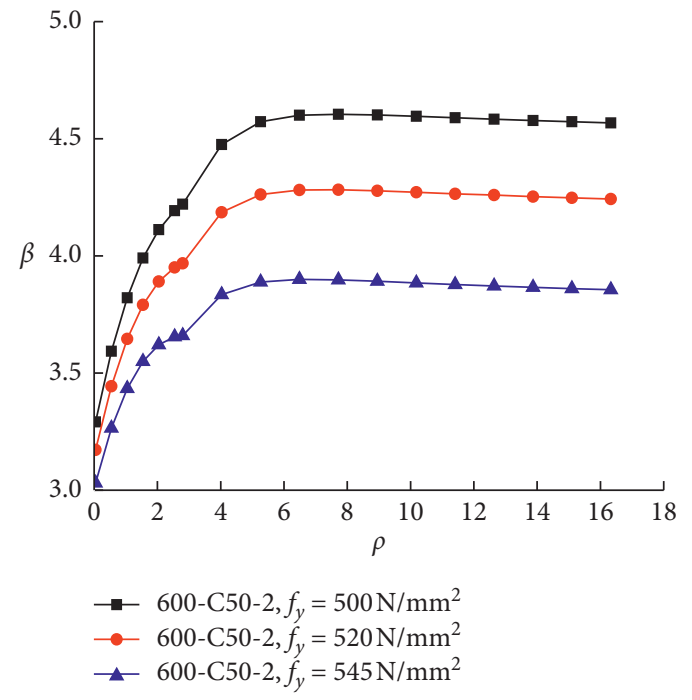

(f)

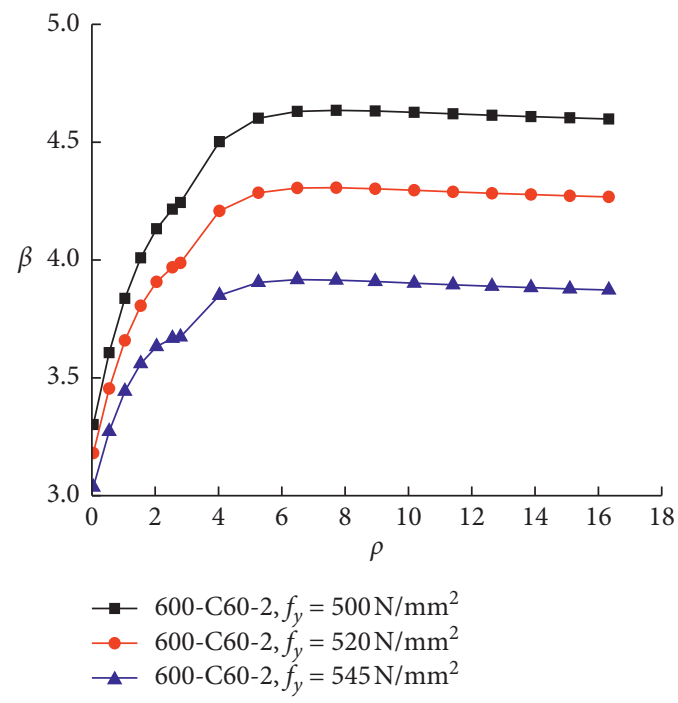

(h)

Figure 9: $\rho-\beta$ Variation curve of each test beam. 


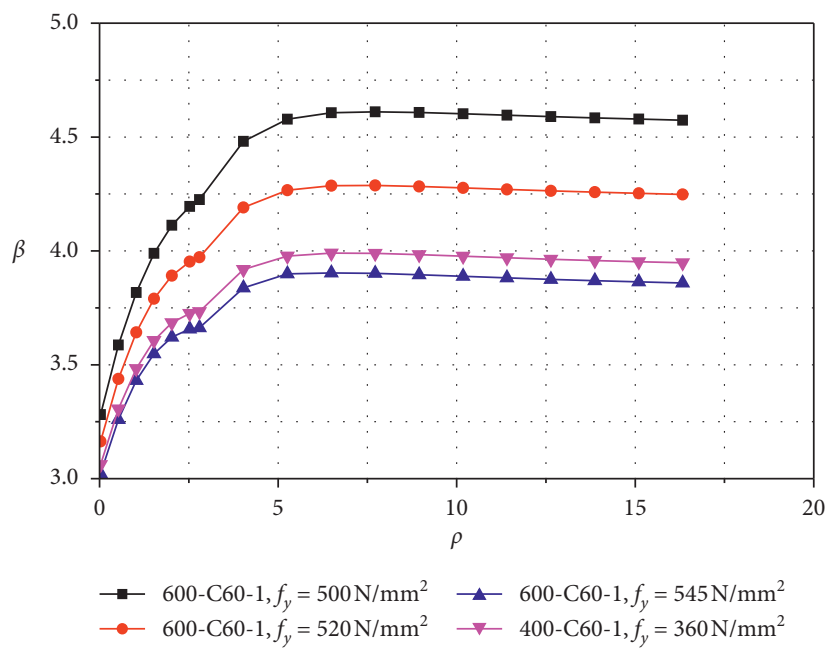

Figure 10: Comparison of the $\rho-\beta$ variation curve of the test beam $600-\mathrm{C} 60-1$ and $400-\mathrm{C} 60-1$.

TABLE 12: The minimum reliable indexes and failure probability of the C60 test beam under different conditions.

\begin{tabular}{lcccccc}
\hline \multirow{2}{*}{ Rebar category } & \multirow{2}{*}{$f_{\mathrm{y}}$} & Reinforcement rate 0.008 & Reinforcement rate 0.005 & Average & Probability of failure & Code value \\
& & 3.062 & - & 3.095 & $9.83 \times 10^{-4}$ & $p_{f}$ \\
\hline \multirow{2}{*}{ HRB400 } & 360 & 3.281 & 3.302 & 3.291 & $4.99 \times 10^{-4}$ & \\
& 500 & 3.163 & 3.181 & 3.172 & $7.57 \times 10^{-4}$ & 3.2 \\
\multirow{2}{*}{ HRB600 } & 520 & 3.023 & 3.036 & 3.030 & $1.22 \times 10^{-3}$ & \\
& 545 & & &
\end{tabular}

TABLE 13: Comparison of experimental flexural bearing capacity $M_{\mathrm{u}}$ with $M_{\mathrm{uc}}$ calculated by code of $520 \mathrm{MPa}$ for the reinforcement design strength.

\begin{tabular}{|c|c|c|c|c|c|}
\hline $\mathrm{RC}$ beam number & $\begin{array}{c}\text { EN1992-1-1 } \\
M_{\mathrm{u}} / M_{\mathrm{uc}}\end{array}$ & $\begin{array}{c}\text { BS5400-4 } \\
M_{\mathrm{u}} / M_{\mathrm{uc}}\end{array}$ & $\begin{array}{c}\text { AASHEO } \\
M_{\mathrm{u}} / M_{\mathrm{uc}}\end{array}$ & $\begin{array}{c}\mathrm{EN} 1991-22003 \\
M_{\mathrm{u}} / M_{\mathrm{uc}}\end{array}$ & $\begin{array}{c}\text { CRC PRESS } \\
M_{\mathrm{u}} / M_{\mathrm{uc}}\end{array}$ \\
\hline $600-C 30-1-1$ & 1.40 & 1.40 & 1.44 & 1.40 & 1.42 \\
\hline $600-C 30-1-2$ & 1.39 & 1.39 & 1.42 & 1.39 & 1.41 \\
\hline $600-C 30-2-1$ & 1.29 & 1.45 & 1.33 & 1.29 & 1.31 \\
\hline $600-C 30-2-2$ & 1.27 & 1.43 & 1.30 & 1.27 & 1.29 \\
\hline $600-C 40-1-1$ & 1.27 & 1.29 & 1.30 & 1.27 & 1.28 \\
\hline $600-C 40-1-2$ & 1.35 & 1.27 & 1.38 & 1.35 & 1.36 \\
\hline $600-C 40-2-1$ & 1.33 & 1.34 & 1.36 & 1.33 & 1.34 \\
\hline $600-C 40-2-2$ & 1.32 & 1.52 & 1.35 & 1.32 & 1.32 \\
\hline $600-C 50-1-1$ & 1.45 & 1.27 & 1.49 & 1.45 & 1.47 \\
\hline $600-C 50-1-2$ & 1.43 & 1.35 & 1.47 & 1.43 & 1.45 \\
\hline $600-C 50-2-1$ & 1.34 & 1.41 & 1.37 & 1.34 & 1.35 \\
\hline $600-C 50-2-2$ & 1.52 & 1.45 & 1.56 & 1.52 & 1.53 \\
\hline 600-C60-1-1 & 1.41 & 1.33 & 1.45 & 1.41 & 1.42 \\
\hline $600-C 60-1-2$ & 1.45 & 1.32 & 1.48 & 1.45 & 1.46 \\
\hline 600-C60-2-1 & 1.46 & 1.45 & 1.49 & 1.45 & 1.46 \\
\hline $600-C 60-2-2$ & 1.46 & 1.45 & 1.49 & 1.45 & 1.46 \\
\hline M & 1.38 & 1.38 & 1.42 & 1.38 & 1.40 \\
\hline$\Delta$ & 0.05 & 0.05 & 0.05 & 0.05 & 0.05 \\
\hline
\end{tabular}


TABLE 13: Continued.

\begin{tabular}{|c|c|c|c|c|c|}
\hline $\mathrm{RC}$ beam number & $\begin{array}{c}\text { EN1992-1-1 } \\
M_{\mathrm{u}} / M_{\mathrm{uc}} \\
\end{array}$ & $\begin{array}{c}\text { BS5400-4 } \\
M_{\mathrm{u}} / M_{\mathrm{uc}} \\
\end{array}$ & $\begin{array}{c}\text { AASHEO } \\
M_{\mathrm{u}} / M_{\mathrm{uc}} \\
\end{array}$ & $\begin{array}{c}\text { EN1991-2 } 2003 \\
M_{\mathrm{u}} / M_{\mathrm{uc}} \\
\end{array}$ & $\begin{array}{c}\text { CRC PRESS } \\
M_{\mathrm{u}} / M_{\mathrm{uc}} \\
\end{array}$ \\
\hline $600-C 30-1-1$ & 1.38 & 1.61 & 1.42 & 1.35 & 1.42 \\
\hline $600-\mathrm{C} 30-1-2$ & 1.37 & 1.60 & 1.41 & 1.34 & 1.41 \\
\hline $600-\mathrm{C} 30-2-1$ & 1.44 & 1.49 & 1.47 & 1.27 & 1.47 \\
\hline $600-C 30-2-2$ & 1.45 & 1.46 & 1.45 & 1.25 & 1.45 \\
\hline $600-C 40-1-1$ & 1.29 & 1.46 & 1.31 & 1.24 & 1.31 \\
\hline $600-C 40-1-2$ & 1.27 & 1.55 & 1.29 & 1.31 & 1.29 \\
\hline $600-C 40-2-1$ & 1.34 & 1.53 & 1.35 & 1.33 & 1.35 \\
\hline $600-C 40-2-2$ & 1.52 & 1.51 & 1.53 & 1.32 & 1.53 \\
\hline $600-\mathrm{C} 50-1-1$ & 1.27 & 1.67 & 1.28 & 1.42 & 1.28 \\
\hline $600-\mathrm{C} 50-1-2$ & 1.35 & 1.65 & 1.36 & 1.40 & 1.36 \\
\hline $600-C 50-2-1$ & 1.41 & 1.54 & 1.42 & 1.32 & 1.42 \\
\hline $600-C 50-2-2$ & 1.45 & 1.75 & 1.46 & 1.50 & 1.46 \\
\hline $600-\mathrm{C} 60-1-1$ & 1.33 & 1.62 & 1.34 & 1.39 & 1.34 \\
\hline $600-C 60-1-2$ & 1.32 & 1.66 & 1.32 & 1.42 & 1.32 \\
\hline $600-\mathrm{C} 60-2-1$ & 1.46 & 1.67 & 1.46 & 1.45 & 1.46 \\
\hline $600-C 60-2-2$ & 1.46 & 1.67 & 1.46 & 1.45 & 1.46 \\
\hline M & 1.38 & 1.59 & 1.40 & 1.36 & 1.40 \\
\hline$\Delta$ & 0.05 & 0.05 & 0.05 & 0.06 & 0.05 \\
\hline
\end{tabular}

Note. $M_{\mathrm{u}}$ in the table is the measured ultimate flexural bearing capacity and $M_{\mathrm{uc}}$ is the calculated value of ultimate flexural bearing capacity obtained by taking the measured yield strength of reinforcement from the current code formulas.

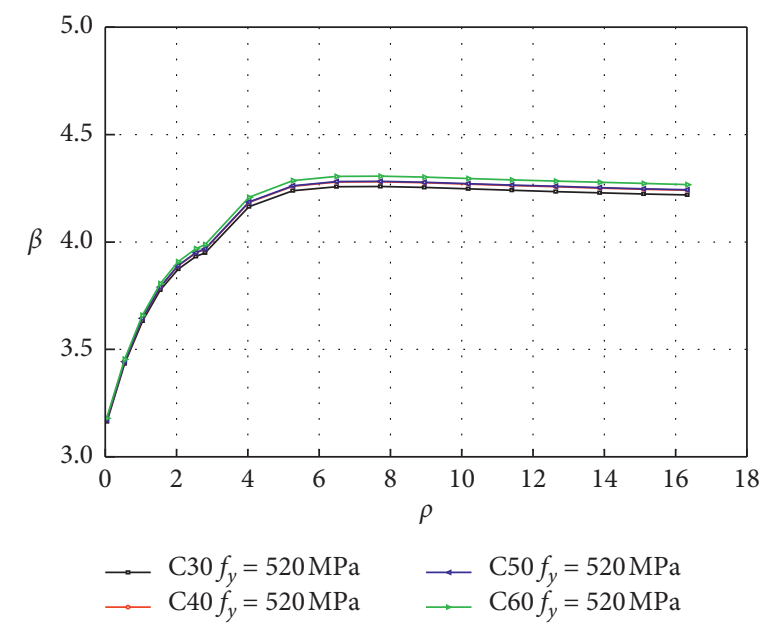

FIGURE 11: $\rho$ - $\beta$ Curve of different concrete strength grades with the reinforcement rate of 0.005 .

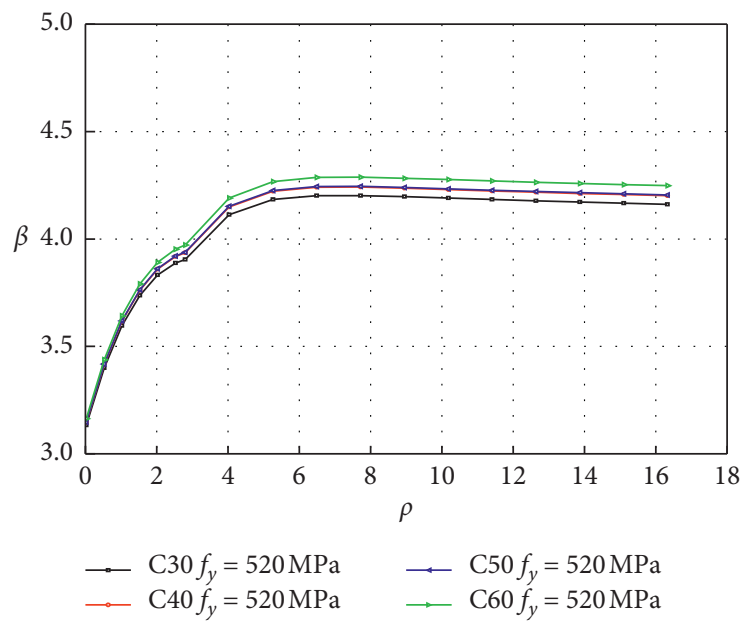

FIGURE 12: $\rho$ - $\beta$ Curve of different concrete strength grades with the reinforcement rate of 0.008 . 


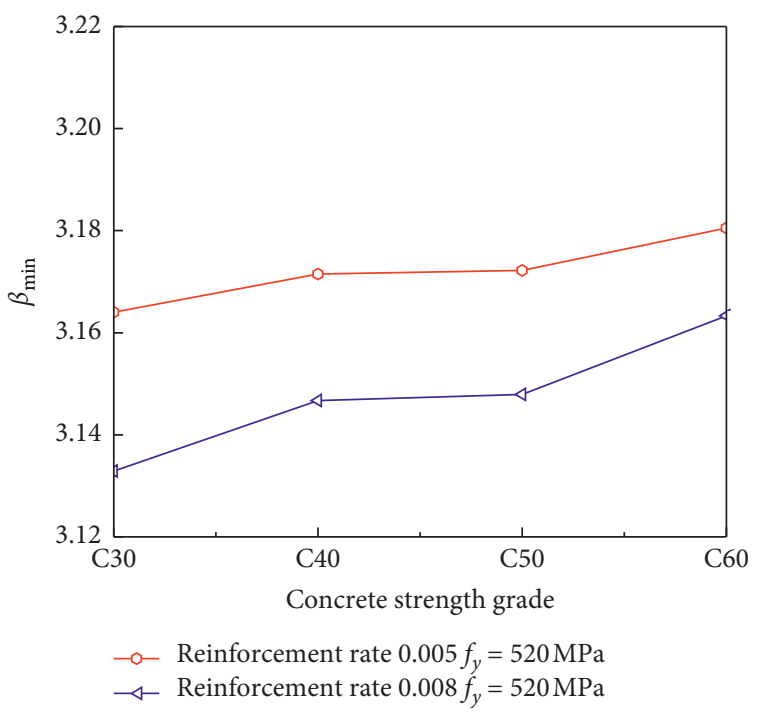

Figure 13: Concrete strength grade- $\beta$ min curve.

TABle 14: Statistical parameters of the minimum reliable index.

\begin{tabular}{lccccccccc}
\hline Reinforcement rate & $\mu_{\beta}$ & $\delta_{\beta}$ & $\mu_{p f}$ & $\mu_{\beta}^{\prime}$ & $\delta_{\beta}^{\prime}$ & $\mu_{p_{f}}^{\prime}$ & $\beta$ & $p_{f}$ & $\mu_{p_{f}}^{\prime} / p_{f}$ \\
\hline 0.005 & 3.172 & 0.002 & $7.57 \times 10^{-4}$ & 3.160 & 0.005 & $7.89 \times 10^{-4}$ & 3.2 & $6.87 \times 10^{-4}$ \\
0.008 & 3.148 & 0.003 & $8.23 \times 10^{-4}$ & 1.15 \\
\hline
\end{tabular}

Note. $\mu_{\beta}$ is the average reliability index of concrete different strength grades corresponding to the reinforcement ratio; $\delta_{\beta}$ is the coefficient of variation of different concrete strength grades corresponding to the reinforcement ratio; $\mu_{p f}$ is the failure probability of the concrete different strength grades corresponding to the reinforcement rate; $\mu_{\beta}^{\prime}$ is the average value of the overall reliability index; $\delta_{\beta}^{\prime}$ is the coefficient of variation of the overall reliability index; $\mu_{p_{f}}^{\prime}$ is the overall average failure probability; $\beta$ is the reliability index in code; and $p_{f}$ is the failure probability in code.

\section{Conclusion}

This paper investigated the flexural bearing capacity of concrete beams reinforced with high-strength steel bars $(600 \mathrm{MPa})$ and concrete of different strengths. Combined with the test data, this study analyzed the applicability of the equations for calculating the flexural capacity an RC beam with $600 \mathrm{MPa}$ grade reinforcement as per different national codes. The reliability of the proposed method of analysis was checked against the experimental performance. The conclusions are as follows:

(1) The expressions and symbols of the equations for calculating the flexural capacity of the normal section of reinforced concrete beams are consistent in various countries, but there are slight differences in the strength calculation and height calculation methods of the equivalent rectangular stress diagram of concrete.

(2) The calculated values of ultimate bearing capacity of RC beams based on codes of different countries were compared with the measured values of ultimate bearing capacity. Equations and calculation procedures that are used to calculate the flexural capacity of beams reinforced with $400 \mathrm{MPa}$ or $500 \mathrm{MPa}$ grade steel could also be used for beams reinforced with $600 \mathrm{MPa}$ grade steel.

(3) On the basis of the experiment, reliability analysis was performed for different design values of yield strength of the $600 \mathrm{MPa}$ grade steel bar. Combined with the experimental results and considering the utilization ratio of steel bar strength, the design value of yield strength of the steel bar was selected to be $520 \mathrm{MPa}$.

\section{Data Availability}

The data used to support the findings of this study are included within the article.

\section{Conflicts of Interest}

The authors declare that they have no conflicts of interest.

\section{Acknowledgments}

The authors would like to express their gratitude to the National Natural Science Foundation of China (no. 51779095) and the Science Technology Innovation Talents in Universities of Henan Province (no. 20HASTIT013).

\section{References}

[1] R. F. Mast, M. Dawood, and S. H. Rizkalla, "Flexural strength design of concrete beams reinforced with high-strength steel bars," ACI Structural Journal, vol. 106, no. 4, pp. 551-552, 2009.

[2] T. K. Hassan, H. M. Seliem, and H. Dawiri, "Shear behavior of large concrete beams reinforced with high-strength steel," ACI Structural Journal, vol. 105, no. 2, pp. 173-179, 2008. 
[3] J. Sperry, D. Darwin, and M. O’Reilly, "Conventional and high-strength steel hooked bars: detailing effects," $A C I$ Structural Journal, vol. 115, no. 1, pp. 247-257, 2018.

[4] X. Ni, S. Cao, and S. Liang, "High-strength bar RC walls: cyclic loading test and strength prediction," Engineering Structures, vol. 198, pp. 1-18, 2019.

[5] P. Zhang, S. Fu, K. Zhang, and T. Zhang, "Mechanical properties of polyvinyl alcohol fiber-reinforced concrete composite containing fly ash and nano- $\mathrm{SiO}_{2}$," Science of Advanced Materials, vol. 10, no. 6, pp. 769-778, 2018.

[6] P. Zhang, Y. Zheng, K. Wang, and K. Zhang, "Combined influence of nano- $\mathrm{CaCO}_{3}$ and polyvinyl alcohol fibers on fresh and mechanical performance of concrete incorporating fly ash," Structural Concrete, vol. 21, no. 2, pp. 724-734, 2019.

[7] P. Zhang, Y. Ling, J. Wang, and Y. Shi, "Bending resistance of PVA fiber reinforced cementitious composites containing nano- $\mathrm{SiO}_{2}, "$ Nanotechnology Reviews, vol. 8, no. 1 , pp. 690-698, 2019.

[8] Y. Li and H. Aoude, "Blast response of beams built with highstrength concrete and high-strength ASTM A1035 bars," International Journal of Impact Engineering, vol. 130, no. 8, pp. 41-67, 2019.

[9] S.-H. Lee, K.-J. Shin, H.-D. Lee, W.-B. Kim, and J.-G. Yang, "Behavior of plate-to-circular hollow section joints of 600 $\mathrm{MPa}$ high-strength steel," International Journal of Steel Structures, vol. 12, no. 4, pp. 473-482, 2012.

[10] H.-L. Yi, L.-X. Du, G.-D. Wang, and X.-H. Liu, "Strengthening mechanism of a new $700 \mathrm{MPa}$ hot rolled high strength steel," Journal of Iron and Steel Research International, vol. 15, no. 2, pp. 76-80, 2008.

[11] Y. Yoshida, T. Obinata, M. Nishio, and T. Shiwaku, "Development of high-strength $\left(780 \mathrm{n} / \mathrm{mm}^{2}\right)$ steel for building systems," International Journal of Steel Structures, vol. 9, no. 4, pp. 285-289, 2009.

[12] D.-H. Kim, J.-H. Kim, and S. Chang, "Material performance evaluation and super-tall building applicability of the 800 MPa high-strength steel plates for building structures," International Journal of Steel Structures, vol. 14, no. 4, pp. 889-900, 2014.

[13] S. E. Quiel, C. Irwin, and C. J. Naito, "Mechanical characterization of normal and high-strength steel bars in RC members under fire," Journal of Structural Engineering, vol. 146, no. 7, pp. 1-17, 2020.

[14] Q. Hao, D. M. Yan, and S. K. Chen, "Effect of high temperature exposure and strain rate on mechanical properties of high-strength steel rebars," Journal of Materials in Civil Engineering, vol. 31, no. 11, pp. 1-11, 2019.

[15] P. Zhang, L. Y. Kang, J. Wang, and J. J. Guo, "Mechanical properties and explosive spalling behavior of steel-fiber-RC exposed to high temperature-a review," Applied Sciences, vol. 10, no. 7, pp. 1-21, 2020

[16] M. A. Saleem, A. Mirmiran, J. Xia, and K. Mackie, "Development length of high-strength steel rebar in ultrahigh performance concrete," Journal of Materials in Civil Engineering, vol. 25, no. 8, pp. 991-998, 2013.

[17] K. A. Harries, B. M. Shahrooz, and A. Soltani, "Flexural crack widths in concrete girders with high-strength reinforcement," Journal of Bridge Engineering, vol. 17, no. 5, pp. 804-812, 2012.

[18] L. Barcley and M. Kowalsky, "Seismic "performance of circular concrete columns reinforced with high-strength steel," Journal of Structural Engineering, vol. 146, no. 2, pp. 1-11, 2020.

[19] J. W. Zhang, C. Li, and X. Y. Li, "Experimental study on seismic behavior of high-strength concrete columns with
HRB600 steel bars," China Civil Engineering Journal, vol. 52, no. 8, pp. 6-17, 2019, in Chinese.

[20] S. Aldabagh and M. S. Alam, "High-strength steel reinforcement (ASTM A1035/A1035M grade 690): state-of-theart review," Journal of Structural Engineering, vol. 146, no. 8, pp. 1-13, 2020.

[21] J. W. Baek, S. H. Kim, and H. G. Park, "Shear-friction strength of low-rise walls with $600 \mathrm{MPa}(87 \mathrm{ksi})$ reinforcing bars," ACI Structural Journal, vol. 117, no. 1, pp. 169-182, 2020.

[22] X. Li, J. Zhang, and W. Cao, "Hysteretic behavior of highstrength concrete shear walls with high-strength steel bars: experimental study and modelling," Engineering Structures, vol. 214, no. 7, pp. 1-16, 2020.

[23] GB/T. 1499.2-2018, Steel for the Reinforcement of ConcretePart 2: Hot Rolled Ribbed Bars, Standardization Administration of China, Beijing, China, 2018, in Chinese.

[24] GB50010-2010, Code for Design of Concrete Structures, China Building Industry Press, Beijing, China, 2010, in Chinese.

[25] DL/T 5057-2009, Design Specification for Hydraulic Concrete Structures, China Electric Power Press, Beijing, China, 2010, in Chinese.

[26] SL/T 191-2008, Design Code for Hydraulic Concrete Structures, China Water Power Press, Beijing, China, 2009, in Chinese.

[27] JTJ267-98, Design Code for Harbour Engineering Concrete Structures, China Communication Press, Beijing, China, 1998, in Chinese.

[28] JTG D62-2012, Code for Design of Highway RC and Prestressed Concrete Bridges and Culverts, China Communication Press, Beijing, China, 2012, in Chinese.

[29] TB10002.3-2005, Code for Design of Railroad RC and Prestressed Concrete Bridges and Culverts, China Railway Press, Beijing, China, 2005, in Chinese.

[30] P. Zhang, Q. Li, J. Wang, Y. Shi, Y. Zheng, and Y. Ling, "Effect of nano-particle on durability of polyvinyl alcohol fiber reinforced cementitious composite," Science of Advanced Materials, vol. 12, no. 2, pp. 249-262, 2020.

[31] P. Zhang, K. X. Wang, and Q. F. Li, "Fabrication and engineering properties of concretes based on geopolymers/alkaliactivated binders-a review," Journal of Cleaner Production, vol. 258, pp. 1-22, Article ID 120896, 2020.

[32] P. Zhang, K. Wang, J. Wang, J. Guo, S. Hu, and Y Ling, "Mechanical properties and prediction of fracture parameters of geopolymer/alkali-activated mortar modified with PVA fiber and nano-SiO2," Ceramics International, vol. 46, no. 12, pp. 20027-20037, 2020.

[33] P. Zhang, Q. F. Li, and Y. Z. Chen, "Durability of steel fiberRC containing $\mathrm{SiO}_{2}$ nano-particles," Materials, vol. 12, no. 13, pp. 1-18, 2019.

[34] H. Zhao, K. Jiang, R. Yang, Y. Tang, and J Liu, "Experimental and theoretical analysis on coupled effect of hydration, temperature and humidity in early-age cement-based materials," International Journal of Heat and Mass Transfer, vol. 146, Article ID 118784, 2020.

[35] H. Zhao, X. Wu, Y. Huang, P. Zhang, Q. Tian, and J Liu, "Investigation of moisture transport in cement-based materials using low-field nuclear magnetic resonance imaging," Magazine of Concrete Research, pp. 1-19, 2019.

[36] H. T. Zhao, K. Jiang, and B. Hong, "Experimental and numerical analysis on coupled hygro-thermo-chemo-mechanical effect in early-age concrete," ASCE Journal of Materials in Civil Engineering, vol. 67, no. 3, pp. 299-331, 2006.

[37] C. Chen, X. D. Yang, and W. Pan, "Experimental research on flexural performance of RC beams with $600 \mathrm{MPa}$ steel bars 
industrial construction," Building Structures, vol. 48, no. 6, pp. 1-4, 2018, in Chinese.

[38] X. Rong, H. C. Wu, and P. Liu, "Experimental research on bending behavior of prestressed concrete beams with $600 \mathrm{MPa}$ steel bars," Journal of Wuhan University, vol. 51, no. 2, pp. 139-143, 2018, in Chinese.

[39] J. X. Zhang, X. Rong, and P. Liu, "Experimental research on crack and flexural behavior of concrete beams with $600 \mathrm{MPa}$ steel bars," Building Structures, vol. 47, no. 24, pp. 89-92, 2017, in Chinese.

[40] GB175-2007, Common Portland Cement, Standardization Administration of China, Beijing, China, 2007, in Chinese.

[41] ACI Committee 318, Building Code Requirement for Structural Concrete (ACI 318-14) and Commentary (ACI 318R-14), American Concrete Institute, Detroit, MI, USA, 2014.

[42] EN1992-1-1, Euro-code2: "Design for Concrete StructuresPart1: General Rules and Rules for Building", European Committee for Standardization, London, UK, 2004.

[43] M. Mustafa, Structural Engineering Handbook, CRC Press LLC, Boca Raton, FL, USA, 1999.

[44] BS5400S, "Concrete and Composite Bridges Part 4;Code of practice for design of concrete bridges," British Standard Institution England, vol. 4, pp. 13-56, 1990.

[45] BS5400S, "Concrete and composite bridges Part 2: specification for loads," British Standard Institution England, vol. 2, pp. 15-72, 2006.

[46] EN1991-2-2003, Eurocode 1;Actions on Structures-Part 2, Traffic Loads on Bridges, Brussels, Belgium, 2003.

[47] AASHTO, AASHTOLRFD Bridge Design Specification, AASHTO, Washington, DC, USA, 2007.

[48] M. Y. Li, The Study of Mechanical Property of HRB400 reinforced, Zhengzhou: Zhengzhou University, Zheng Zhou, China, 2003, in Chinese.

[49] L. Y. Na, The Experimental Study on the Crack Behavior of Concrete Bending Members Reinforced with HRB400 Steel, $\mathrm{Hu}$ Nan: Hunan University, Changsha, China, 2006, in Chinese.

[50] H. J. Xiao, Experimental Research on Bend Behavior of HRB400 RC Beams, Zhengzhou: Zhengzhou University, Zheng Zhou, China, 2006, in Chinese.

[51] W. J. Ge and J. W. Z. H. Dai, "Experimental Study on the flexural behavior of concrete beam reinforced with HRBF400 steel bars," Industrial Construction, vol. 41, no. 6, pp. 71-74, 2011, in Chinese.

[52] H. L. Shao, R. Q. Ma, and J. Ge, "The theoretical analysis on bend performance of RC beams with $600 \mathrm{MPa}$," in Proceedings of the Industrial Construction 2016 Supplement II, pp. 251255, Industrial Construction Press, New York, NY, USA, August 2016, in Chinese.

[53] C. Cheng, Experimental Study on Mechanical Properties of $R C$ Members with $600 \mathrm{MPa}$ Steel Bar, Kunming University of Science Technology, Kunming, China, 2016, in Chinese.

[54] P. Zhang, The Experimental Study on Bending Behavior of RC Beams with $500 \mathrm{MPa}$ Steel Bar, Hebei University of Technology, Tianjin, China, 2007, in Chinese.

[55] T. Zhang, The Study of Mechanical Property of HRB500 reinforced, Zhengzhou: Zhengzhou University, Zhengzhou, China, 2004, in Chinese.

[56] S. Z. Shang, Experimental Research on Flexural Performance of Concrete Beam Reinfored with High-Strength Rebars, Tongji University, Shanghai, China, 2007, in Chinese.

[57] Y. Y. Li, Experimental Research on Behaviors of RC Beams with $500 \mathrm{MPa}$ Steel Bars, Tianjin University, Tianjin, China, 2007, in Chinese.
[58] P. Liu, Experimental and Theoretical Research on Beams with HRB 500 High Strength Steel Bars, Hebei University of Technology, Tianjin, China, 2012, in Chinese.

[59] F. B. Xu, Experimental and Theoretical Research on Flexural Behavior of RC Beams with HRB 500 Bars, Hu Nan: Hunan University, Changsha, China, 2007, in Chinese.

[60] S. A. Ashour, "Effect of compressive strength and tensile reinforcement ratio on flexural behavior of high-strength concrete beams," Engineering Structures, vol. 22, no. 5, pp. 413-423, 2000.

[61] X. Rong, H. T. Wang, and P. Liu, "Experimental study on bending behavior of RC beam with $600 \mathrm{MPa}$ steel bar," Journal of Harbin University of Technology, vol. 44, no. 5, pp. 86-89, 2015, in Chinese.

[62] A..W. Li, Experimental Research on Flexural Bearing Capacity of RC Beams with HRBF500 and Reliability Analysis, Huqiao University, Quanzhou, China, 2011, in Chinese.

[63] M. Zhang, Structural Reliability Analysis: Methods and Procedures, Science Press, Beijing, China, 2009, in Chinese.

[64] J. X. Gong and W. W. Wei, The Principle of Engineering Structure Reliability Design, Machinery Industry Press, Beijing, China, 2007, in Chinese.

[65] GB 50153-2008, Unified Standard for Reliability Design of Engineering Structures, China Building Industry Press, Beijing, China, 2008, in Chinese.

[66] GB 50009-2012, Load Code for the Design of Building Structures, China Building Industry Press, Beijing. China, 2012, in Chinese.

[67] J. Zhang, S. G. Liu, and J. H. Ding, "Analysis of the reliability of the bending carrying capacity of the RC beams," in Proceedings of the Beijing Force Society. The Paper Collection of the 20th Annual Conference of the Beijing Force Society, pp. 750-753, Beijing Force Society, Beijing, China, November 2014, in Chinese.

[68] F. Bai, Discussion of the Safety and Life Evaluation Methods of $R C$ Flexural and Compression-Flexure Members Based on Reliability, South China University of Technology, Guangzhou, China, 2012, in Chinese.

[69] Z. He and Y. C. Huang, "Reliability evaluation for flexural capacity sdesign of concrete beams reinforced with FRP rebars," Journal of Harbin University of Technology, vol. 4, pp. 650-655, 2007, in Chinese. 